\title{
Wild roses and hawthorns of urban area: a case study of Piła in Poland
}

\section{Anna Sołtys-Lelek ${ }^{1 *} \&$ Wojciech Gruszka²}

\author{
${ }^{1}$ Ojców National Park, 32-045 Sułoszowa, Ojców 9, Poland \\ ${ }^{2}$ Department of Biology, Morphological and Health Sciences, Faculty of Physical Culture in Gorzów Wlkp., University School of Physical \\ Education in Poznań, Estkowskiego 13, 66-400 Gorzów Wlkp., Poland \\ * corresponding author (e-mail: ana_soltys@wp.pl)
}

\begin{abstract}
The paper presents a study on the distribution of wild roses and hawthorns in the town of Piła (NW Poland). The main purpose of the study was to provide a full list of wild Crataegus and Rosa taxa growing in the researched area. Field studies (2014-2015) and formerly published data made it possible to recognize 19 taxa, among them 14 native taxa (including two rose nothospecies), 4 anthropophytes and 1 hybrid. Eleven new taxa were found in the explored area during the studies. These were: Crataegus rhipidophylla, C. × macrocarpa, $C . \times$ subsphaericea, $C . \times$ media 'Rubra Plena', Rosa majalis, $R$. villosa, $R$. rubiginosa, $R$. $\times$ subcollina, $R$. glauca, $R$. rugosa, $R$. multiflora and interspecific hybrid Rosa canina $\times R$. rubiginosa.
\end{abstract}

Key words: Rosa, Crataegus, critical taxa, nothospecies, hybrid, native species, anthropohyte, distribution

\section{Introduction}

Being fairly common shrubby plants, roses and hawthorns are not so easy to recognize and quite complicated in systematics (Popek 1996). These genera are characterized by high species polymorphism. Hybridism, polyploidy and apomixis are factors contributing to the above character (Klášterská \& Klášterský 1974; Ptak 1986, 1989; Wells \& Phipps 1989; Christensen 1992; Nybom et al. 1997; Werlemark 2000).

Data on the distribution of roses and hawthorns in Poland are not complete (Zając \& Zając 2001). The largest number of stands was reported for common species like: Rosa canina L., R. dumalis Bechst., Crataegus monogyna Jacq. or C. laevigata (Poir.) DC. (Zieliński 1985, 1987; Christensen 1992; Popek 1996, 2002). There is still a lack of evidence confirming the occurrence of rarer taxa in Poland, also of data concerning their distribution. Therefore, the subject requires further studies.

The earliest data concerning the distribution of roses in the examined area come from the first half of the 20th century. Such species as: Rosa glauca Vill. var. complicata Christ. (=R. dumalis Bechst.), R. coriifolia Fries. var. typica Christ. (=R. dumalis Bechst.), R. subcanina
Hayek (= Rosa $\times$ subcanina $($ H. Christ) R. Keller), $R$. inodora Schwertschl var. genuina Schwertschl $(=R$. inodora Fr. var. inodora), $R$. canina $\mathrm{L}$. var. dumalis Baker and R. dumetorum Thuill. (= R. canina L.) (Frase 1935; Enderlein 1938; Abromeit et al. 1898-1940) were provided within the records; however, recently, they are mostly distinguished as synonymous ones (Popek 1966; Henker 2000). Later on, Zieliński (1981a) reported Rosa sherardii Dav. and confirmed the occurrence of $R$. canina. As far as hawthorns are concerned, the only data confirming Crataegus monogyna Jacq. and C. laevigata (Poiret) DC occurrence can be found in "Distribution Atlas of Vascular Plants in Poland" - ATPOL (Zając \& Zając 2001).

The performed studies focused both on supplying and analyses of recent species content of critical genera Crataegus L. and Rosa L., occurring within the boundaries of the town of Piła (NW Poland).

\section{Study area}

Piła $\left(102.7 \mathrm{~km}^{2}\right.$ area) is a town in northwestern Poland. It is situated in the Greater Poland Voivodeship $53.149^{\circ} \mathrm{N} 16.739^{\circ} \mathrm{E}$ (Program... 2005-2012). According to the physico-geographical regionalization of Poland, 


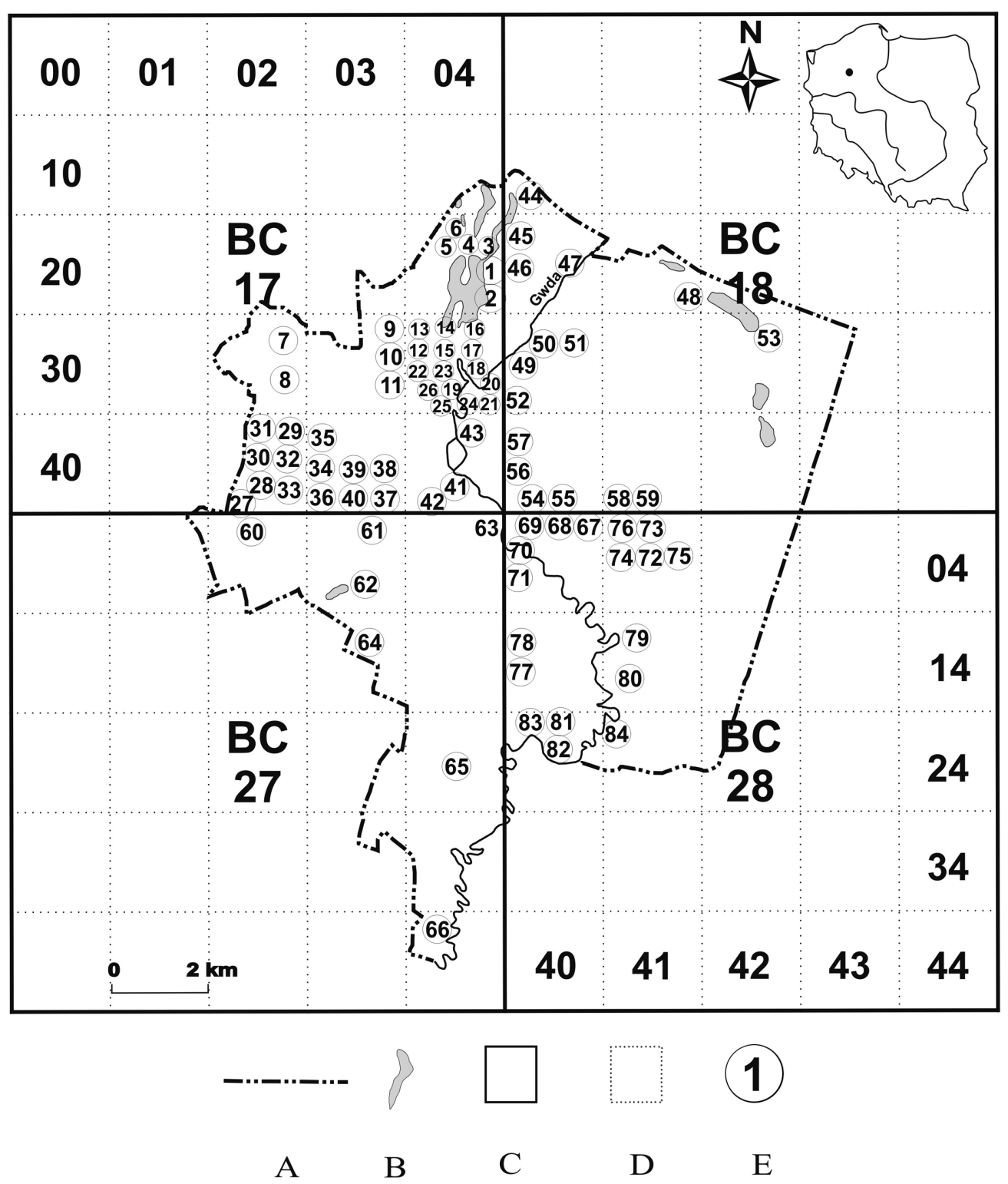

Fig. 1. Location of Crataegus localities in the study area against the background of the ATPOL grid square system Explanations: A - city border, B - water bodies, C - ATPOL $10 \times 10 \mathrm{~km}$ squares, D - ATPOL $2 \times 2 \mathrm{~km}$ squares (stands), E - localities of Crataegus species (see Appendix 1)

Piła is situated in the South Pomeranian Lake District macroregion (Pojezierze Południowopomorskie) and the Gwda River Valley mezoregion (Kondracki 2001). It is located in the $\mathrm{BC} 17, \mathrm{BC} 18, \mathrm{BC} 27$ and $\mathrm{BC} 28$ squares of ATPOL (Zając 1978).

The average annual air temperature varies between 7.5 $7.8^{\circ} \mathrm{C}$, while annual average precipitation fluctuates from 525-550 mm (Koźmiński \& Michalska 2001; Farat 2004). The average duration of snow cover in the Piła region ranges from 48-58 days (Bednorz 2001). The vegetation period is long and lasts 220 days (Kondracki 1967).

The town is divided by the Gwda river valley. The look of contemporary Piła is the result of people's longtime interference with local landscape. Green areas situated in Piła cover a significant part of the town and include: parks, park-like facilities, numerous flower beds, sound barriers, alamedas, woodlots and cemetery green spots. Human interference in the 'green shape' of Piła is strongly visible. Only the tiny spots of natural vegetation are left, mainly on poor sites, neither available nor accessible for further settlement or potential cultivation.

\section{Material and methods}

Floristic material was collected in the years 20142015, within the town limits, following the method based on ATPOL $10 \times 10 \mathrm{~km}$ squares. Each of the squares was divided into 25 smaller ones $(2 \times 2 \mathrm{~km})$, according to ATPOL instructions (Zając 1978). Each 


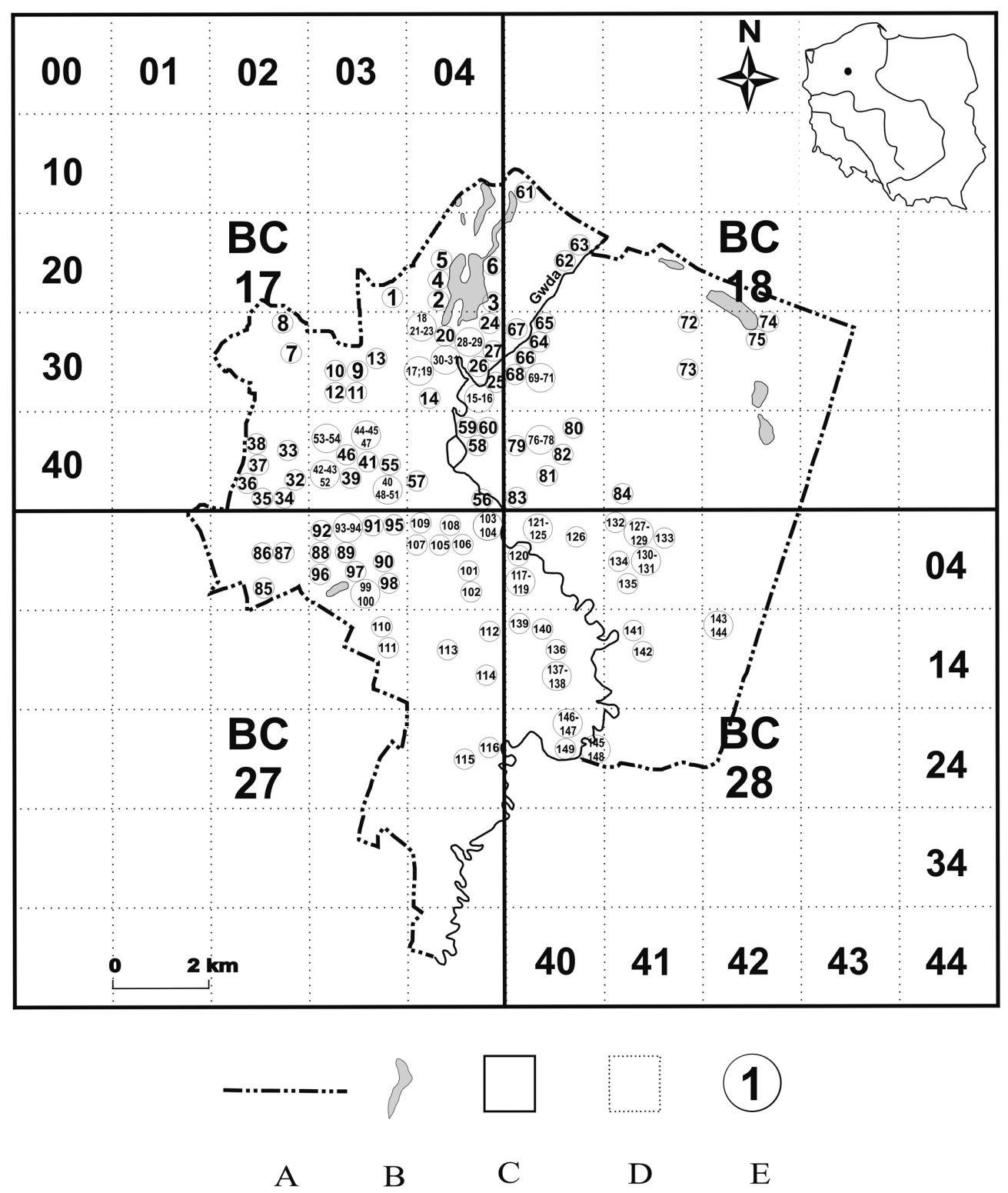

Fig. 2. Location of Rosa localities in the study area against the background of the ATPOL grid square system Explanations: A - city borders, B - water bodies, C - ATPOL $10 \times 10 \mathrm{~km}$ squares, D - ATPOL $2 \times 2 \mathrm{~km}$ squares (stands), E - localities of Rosa species (see Appendix 2)

of the 39 squares $\left(4 \mathrm{~km}^{2}\right)$ was treated as a single stand (Figs. 1-2, Appendices 1-2).

All herbarium materials were deposited in the Herbarium of the University School of Physical Education, Gorzów Wielkopolski (Poland). Data from literature were also included. Taxonomic approach and nomenclature were based on the works of Popek (1996), Zieliński (1985, 1987), Henker (2000) and Christensen (1992, 1997). Geographical elements for each species follow Popek (2007) and Zając \& Zając (2009). For alien species (anthropophytes), their native ranges are given.

The frequency of taxa occurrence was defined on the basis of the number of stands: 5-9 - rare species, 10-15 - not very frequent, 16-20 - quite frequent, 2125 - frequent, 26-30 - very frequent, $>30-$ common.

\section{Results}

The list of species from the Crataegus and Rosa genera growing in the explored area contained 19 taxa: 6 species of hawthorns (Crataegus L.) belonging to Erianthae and Crataegus subseries (including 3 nothospecies) and 13 taxa of roses (Rosa L.) belonging to the sections: Rosa (2 species), Caninae DC. em. H. Christ (10 taxa) and Synstylae DC. (1 species), among them - 9 native species (including 2 nothospecies, 1 hybrid form) and 3 anthropophytes. It is worth mentioning that the following 12 taxa were new for the flora of Piła: Crataegus rhipidophylla, C. ×macrocarpa, C. × subsphaericea, C. $\times$ media 'Rubra Plena', Rosa majalis, R. villosa, $R$. rubiginosa, $R$. $\times$ subcollina also the antropophytes: 
R. glauca, R. rugosa, R. multiflora and the interspecific hybrid Rosa canina $\times R$. rubiginosa.

\section{List of species}

Abbreviations and symbols used in the list of species: geographical elements, Asia - Asian element, CE - European-temperate subelement, CE: a-ne-Alpine-northern-European distributional type, CE: ce-g-European-temperate montane group, $\mathrm{M}$ - Mediterranean element, ES - Euro-Siberian sub-element, IR - Irano-Turanian element; $\mathrm{e}$ - eastern, $\mathrm{n}$ - northern, $\mathrm{w}$ - western; sa - extension in the beginning of diagnosis to the Atlantic region of Europe

\section{Genus Crataegus L.}

\section{Ser. Crataegus}

\section{Subser. Erianthae}

\section{Crataegus laevigata (Poiret) DC.}

A very rare species, reported by Leda (2001a) from $\mathrm{BC} 17$ and $\mathrm{BC} 18$ ATPOL squares.

The species widespread in the territory of Poland, most frequent in the northern and south-western part of the country (Christensen1992; Leda 2001a). CE-M(n).

\section{Subser. Crataegus}

\section{Crataegus rhipidophylla Gand. var. rhipidophylla}

New for the study area, very rare, reported from one locality (37).

Crataegus rhipidophylla Gand. var. rhipidophylla is widespread in the territory of Poland, except for the north-east part of the country. Fairly numerous in the Carpathian Mountains and in the KrakowskoCzęstochowska Upland (Jurassic Rock Upland) (Christensen 1992; Sołtys-Lelek 2011, 2012; Oklejewicz \& Vončina 2012; Oklejewicz et al. 2013, 2014, 2015). CE-M(e)-IR(w).

\section{Crataegus monogyna Jacq. var. monogyna}

A very frequent species -66 localities $(1,2,3,5,7$, $8,9,10,11,12,13,14,15,16,17,18,19,20,26,27$, $28,29,31,32,34,36,35,41,42,43,44,45,46,47$, $48,49,51,52,53,54,55,56,57,58,59,60,62,63,64$, $65,66,67,68,69,70,71,72,73,74,75,76,77,79,81$, $82,83)$ from 26 stands. Formerly reported from BC17, BC18, BC27 and BC28 (Leda 2001b).

The only variety occurring in Poland (Christensen 1992), very common in the whole territory (Christensen 1992; Leda 2001b; Barabasz-Krasny \& Sołtys-Lelek 2011; Sołtys-Lelek 2011, 2012; Oklejewicz \& Vončina 2012; Oklejewicz et al. 2013, 2015). saCE-M-IR(w).

Crataegus $\times$ macrocarpa Hegetschw. [C. laevigata (Poiret) DC. $\times$ C. rhipidophylla Gand.]

New for the study area, a very rare hybrid, reported from four localities, occurs in two varieties.

The taxon found in the localities situated mainly in the west, north, south and south-east outskirts of Poland (Christensen 1992; Sołtys-
Lelek 2011, 2012; Oklejewicz \& Vončina 2012; Oklejewicz et al. 2013, 2014, 2015). CE.

- Crataegus ×macrocarpa Hegetschw. nothovar. macrocarpa [C. laevigata (Poiret) DC. $\times C$. rhipidophylla Gand. var. rhipidophylla]. Syn.: C. ×macrocarpa var. curvisepaloides HrabetováUhrová

A very rare variety, reported from three localities $(21,33,80)$ and three stands.

The taxon found mainly in the western regions of Poland, sporadic in north and south Poland (Christensen 1992; Sołtys-Lelek 2011, 2012).

- Crataegus ×macrocarpa Hegetschw. nothovar. calycina (Peterm.) Kerguélen [C. laevigata (Poiret) DC. $\times$ C. rhipidophylla Gand. var. ronnigeri (K. Malý) Janjić] Syn.: Crataegus $\times$ macrocarpa Hegetschw. nothovar. hadensis (Hrabetová-Uhrová) Christensen, C. calycina Petermann, C. calciphila Hrabetová-Uhrová A very rare variety, 1 record (61) from $\mathrm{BC} 2703$. Reported only from the south and middle-west parts of Poland (Christensen 1992; Sołtys-Lelek 2011).

Crataegus $\times$ subsphaericea Gand. [C. monogyna Jacq. $\times$ C. rhipidophylla Gand.]

New for the study area, a rare hybrid reported from 7 localities, occurs in two varieties.

The taxon reported mainly from the north and north-west Poland, also from the Carpathian and Holy Cross Mountains (Karpaty, Góry Świętokrzyskie). Incidentally reported from single, sporadic localities (Christensen 1992; Barabasz-Krasny \& Sołtys-Lelek 2011; Sołtys-Lelek 2011, 2012; Oklejewicz \& Vončina 2012; Oklejewicz et al. 2013, 2014, 2015). CE-M(e)-IR(w).

- Crataegus × subsphaericea Gand. nothovar. subsphaericea $[$ C. monogyna Jacq. $\times C$. rhipidophylla Gand. var. rhipidophylla]

A rare variety, 10 localities $(4,6,22,23,24,25$, 39,50, 78, 84) from 6 stands (Fig. 3).

The variety reported mainly from the north and north-west regions of Poland, incidentally, from east and south outskirts of the country (Christensen 1992; Soltys-Lelek 2011, 2012).

- Crataegus × subsphaericea Gand. nothovar. domicensis (Hrabetová-Uhrová) Christensen [ $C$. monogyna Jacq. $\times$ C. rhipidophylla Gand. var. ronnigeri (K. Malý) Janijić]

A very rare variety, 1 locality (30) from a stand in BC1742. (Fig. 4).

The variety reported only from the middle and west parts of Poland (Christensen 1992).

Crataegus ×media Bechst. 'Rubra Plena' [Crataegus laevigata (Poiret) DC. $\times$ Crataegus monogyna Jacq.]

New for the study area, anthropophyte, the variety cultivated in towns or the leftover after former gardens -2 localities $(38,40)$ from one stand.

The double-flowered decorative variety, often cultivated, distributed in the whole territory of Poland (Seneta 1994). CE-M. 


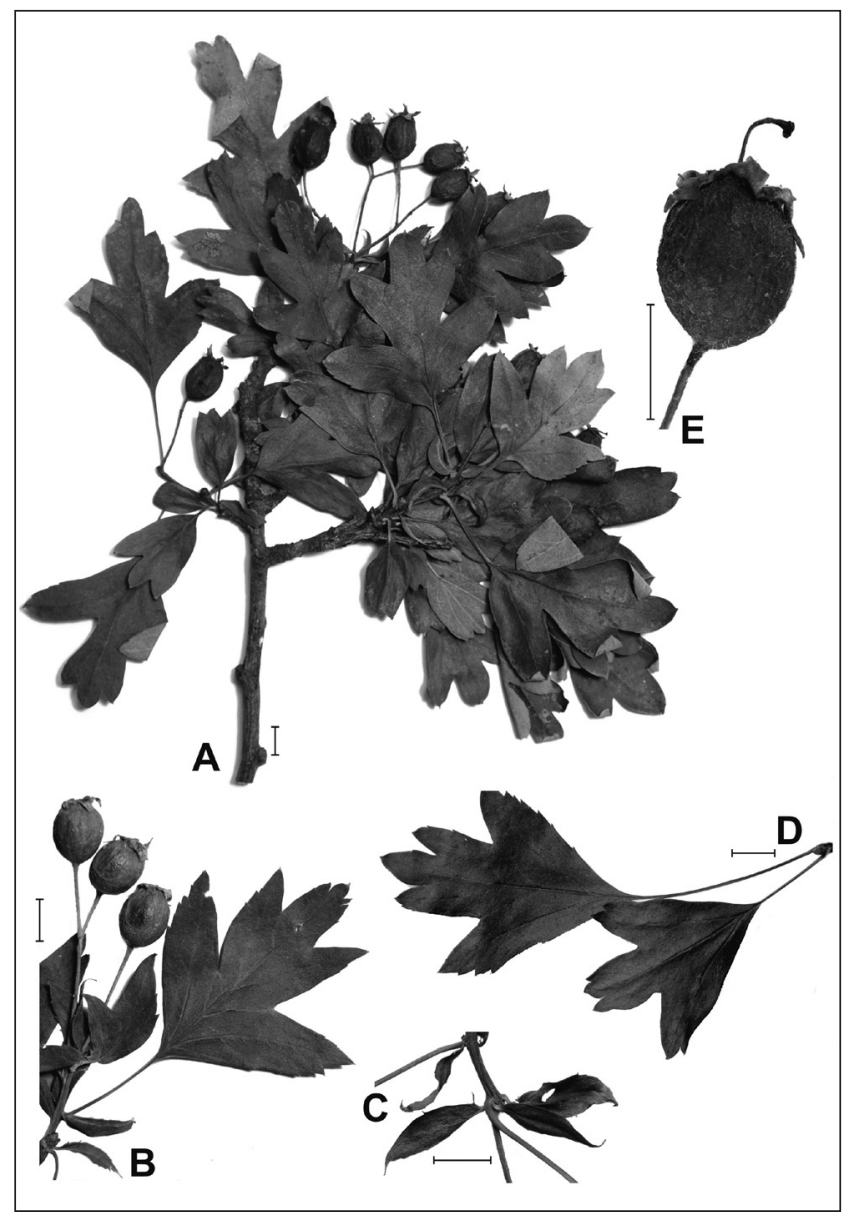

Fig. 3. Crataegus $\times$ subsphaericea Gand. nothovar. subsphaericea Explanations: A - fragment of a shoot, B - leaf of a flowering short shoot, $\mathrm{C}$ - stipule of a leaf of a flowering short shoot, D - leaves of a short shoot, $\mathrm{E}-$ fruit. Solid bar $=1 \mathrm{~cm}$

\section{Genus Rosa L.}

I. Sect. Rosa (= sect. Cinnamomeae DC.)

\section{Rosa rugosa Thunb.}

New for the study area, anthropophyte, not very frequent, 18 localities $(3,11,25,32,36,39,42,43$, $55,81,88,102,107,126,128,140,141,145)$ from 13 stands.

The species (Far East origin) grows in the whole territory of Poland, in both natural and cultivated habitats (Zieliński 1987), mostly common in south and south-west Poland and Kielce region (Zając \& Zając 2001; Gutkowska \& Niedźwiecka 2014; Marciniuk et al. 2015). Asia.

\section{Rosa majalis Herrm. var. majalis}

New for the study area, very rare, 2 localities (45, $105)$ in two stands, a cultivated specimen running wild. The species and variety are known from a few localities scattered in the whole Poland, beyond the range limits (Zieliński 1981b; Popek 1996, 2002; Zieliński \& Popek 2001a; Gutkowska \& Niedźwiecka 2014). ES(w, n).

\section{Sect. Caninae DC. emend. H. Christ.}

Rosa glauca Pourr. var. glauca. [Syn.: R. rubrifolia Vill.]

New for the study area, anthropophyte, very rare, 1 locality (125), a cultivated specimen running wild. Frequently cultivated in the area of whole Poland, no wild specimens reported so far. The closest natural locality found in the Tatry Bielskie Mountains (Zieliński 1987; Popek 2002). CE: ce-g.

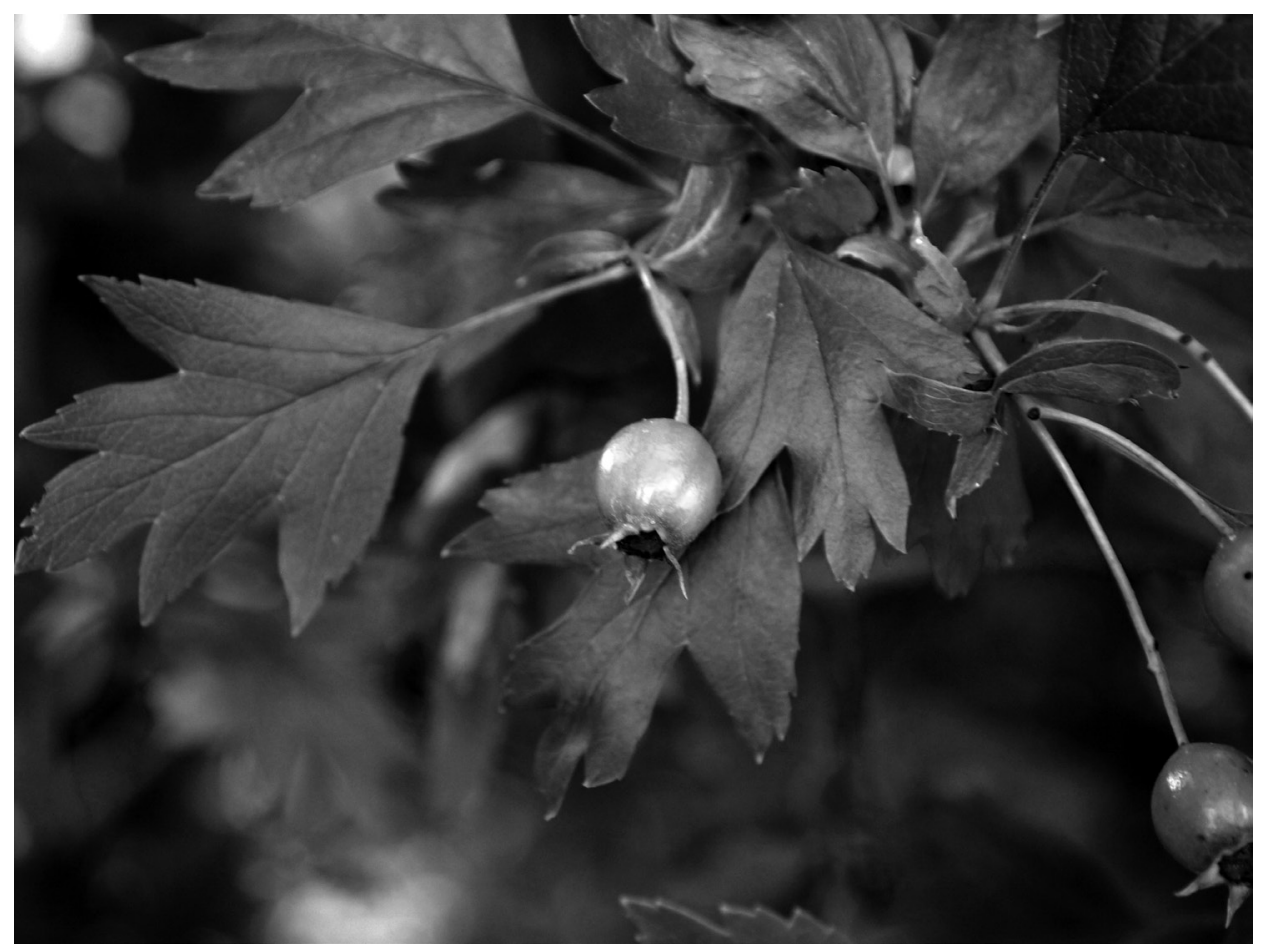

Fig. 4. Crataegus $\times$ subsphaericea Gand. nothovar. domicensis (Hrabetová-Uhrová) Christensen (photo by W. Gruszka, Piła, Wypoczynkowa str., 2015) 
Rosa dumalis Bechst. [Syn.: R. afzeliana Fr., R. glauca Vill, $R$. caesia $\mathrm{Sm} .$, . coriifolia $\mathrm{Fr}$.]

Not very frequent species, in the Lake Rudnickie area, earlier reported by Frase (1935) as Rosa glauca Vill. var complicata Christ. and $R$. coriifolia Fries. var. typica Christ. Currently found four varieties in 14 stands.

Growing in the whole territory, mainly the lowland and foothill parts of Poland (Zieliński 1981c; Zieliński \& Popek 2001b; Popek 2002; Gutkowska \& Niedźwiecka 2014). CE-M(n).

- var. afzeliana (Fr.) Boulenger

A very rare variety, 4 localities $(64,66,74,124)$ in 3 stands.

A common variety growing in the whole territory of Poland (Popek 1996).

- var. dumalis

Not a very frequent variety, 14 localities $(2,12$, $15,19,21,23,47,53,71,89,92,123,133,134)$ in 8 stands.

Very common in the whole country (Popek 1996).

- var. coriifolia (Fr.) Boulenger

Rare variety, 8 localities $(30,46,62,82,95$, $112,114,144)$ in 7 stands. The record 82 also concerns Rosa dumalis Bechst. var. coriifolia (Fr.) Boulenger for. tristis (A. Kerner) Popek Very common variety in Poland (Popek 1996).
- var. caesia (Sm.) Boulenger

A very rare variety, 3 localities $(48,93,109)$ in 3 stands.

Not frequent variety in Poland (Popek 1996).

\section{Rosa villosa $\mathrm{L}$. var. villosa}

New for the study area, very rare, 1 locality (139) - a specimen collected from the cemetery hedge. The original habitat - unknown (Fig. 5).

Through Poland runs the southern limit of the species range. The only wild form of the species grows in the south west part of Poland (Zieliński 1981a; Zieliński \& Popek 2001c). The only variety in Poland was reported by Popek 1996. CE-M.

\section{Rosa sherardii Davies}

Rare, two varieties reported from 7 stands.

Frequent in Poland. Very common in the lowland and foothill parts of the country (Zieliński 1981d; Popek 1996; Zieliński \& Popek 2001d; Gutkowska \& Niedźwiecka 2014). CE:a-ne.

- var. sherardii

Rare, 6 localities $(49,77,120,138,142,147)$ in 6 stands.

The widespread variety in the whole Poland (Popek 1996).

- var. collivaga (Cottet) Boulenger

Very rare, 1 locality (130).

The species grows in west and north parts of Poland. Its southern occurrence was reported only from the Pieniny

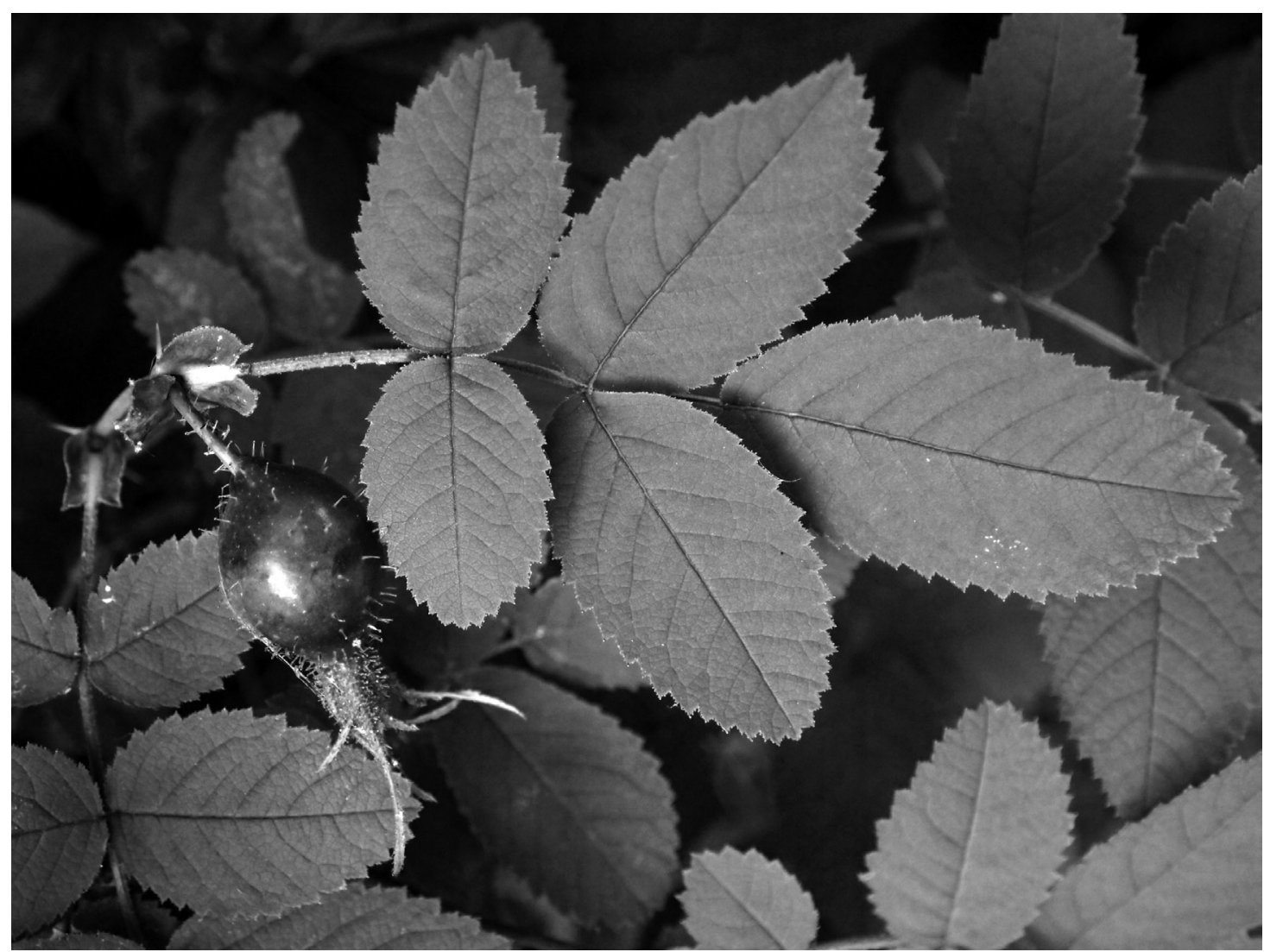

Fig. 5. Rosa villosa L. (photo by W. Gruszka, Piła, municipal cemetery, 2015) 
Mountains and Kraków-Częstochowa Upland (Popek 1996; Sołtys-Lelek 2011). The species formerly reported by Zieliński (1981a), ATPOL BC17 (Popek 2002).

\section{Rosa rubiginosa $\mathrm{L}$.}

New for the study area, two varieties of not very frequent species, reported from 10 stands.

Frequent in the whole Poland. Very common in lowlands, foothills and the South Polish Uplands (Kaczmarek 1972; Popek 2002; Gutkowska \& Niedźwiecka 2014). sa-CE-M(n).

- var. umbellata (Leers) Dumort.

Rare, 12 localities $(5,40,51,68,73,76,85,94$, $119,121,129,131)$ in 9 stands.

Distributed in the whole Poland, a very common variety (Popek 1996).

- var. jenensis (M. Schulze) H. Christ.

Very rare, 1 locality (111).

On the scale of Poland, the variety recorded only in the Szczecin area and Skotniki Małe in the Nida River valley (Holzfuss 1924; Soltys-Lelek 2012).

\section{Rosa inodora Fr. var. inodora}

The variety named $R$. inodora Schwertschl var. genuina Schwertschl. found close to the Lake Rudnickie, reported by Enderlein (1938), Not verified since then. Through Poland runs the northeastern limit of the species range. It occurs mainly in lowlands and the South Polish Uplands. The species and variety common (Kaczmarek 1973; Popek 2002). CE (w).

\section{Rosa canina L.}

A frequent species, formerly reported by Abromeit et al. (1898-1940) as R. dumetorum Thuill. Later, reported by Zieliński (1981e) from BC17, BC18 and BC28 (Popek 2002). Currently found five varieties in 23 stands. Very common in the whole territory of Poland (Zieliński \& Popek 2001e; Popek 2002; Gutkowska \& Niedźwiecka 2014). sa-CE-M-IR.

- var. canina

Very rare, 2 localities $(91,101)$ in 2 stands. A rare variety in Poland (Popek 1996).

- var. andegavensis (Bastard.) Desp.

Very rare, 3 localities $(27,37,137)$ in 3 stands. A very rare variety, reported only from the Wielkopolska Lowland, Sudeckie Foothills and Wysoczyzna Płocka (Popek 1996).

- var. dumalis Baker

Quite frequent, 37 localities $(1,4,6,7,9,10,14$, $17,18,22,24,26,31,33,38,41,44,52,54,56$, $57,58,59,72,75,78,79,80,86,90,98,104,106$, $113,117,132,149)$ in 18 stands. The variety formerly reported by Abromeit et al. (1898-1940). A common variety in Poland (Popek 1996).

- var. deseglisei (Boreau) Crépin (Fig. 6). Very rare, 2 localities $(60,108)$ in 2 stands.
Arare variety, reported from the South Polish Uplands, Niecka Nidziańska, Beskid Śląski Mountains and Szczecińska Upland (Popek 1996; Sołtys-Lelek 2012).

- var. corymbifera (Borkh.) Boulenger

Very rare, 3 localities $(50,69,146)$ in 3 stands. Very common (Popek 1996).

\section{Rosa $\times$ subcanina $(\mathrm{H}$. Christ) R. Keller}

Quite frequent, 26 localities $(8,16,20,29,34,35,61$, $63,65,67,84,87,96,97,99,100,103,110,115,116$, $122,127,135,136,143,148)$ in 17 stands. Reported earlier from the Lake Rudnickie locality (Frase 1935). The form of hybrid origin, no hairy leaves, reported by Henker (2000) in the range of species. Its distribution in Poland requires further studies. CE-M(n).

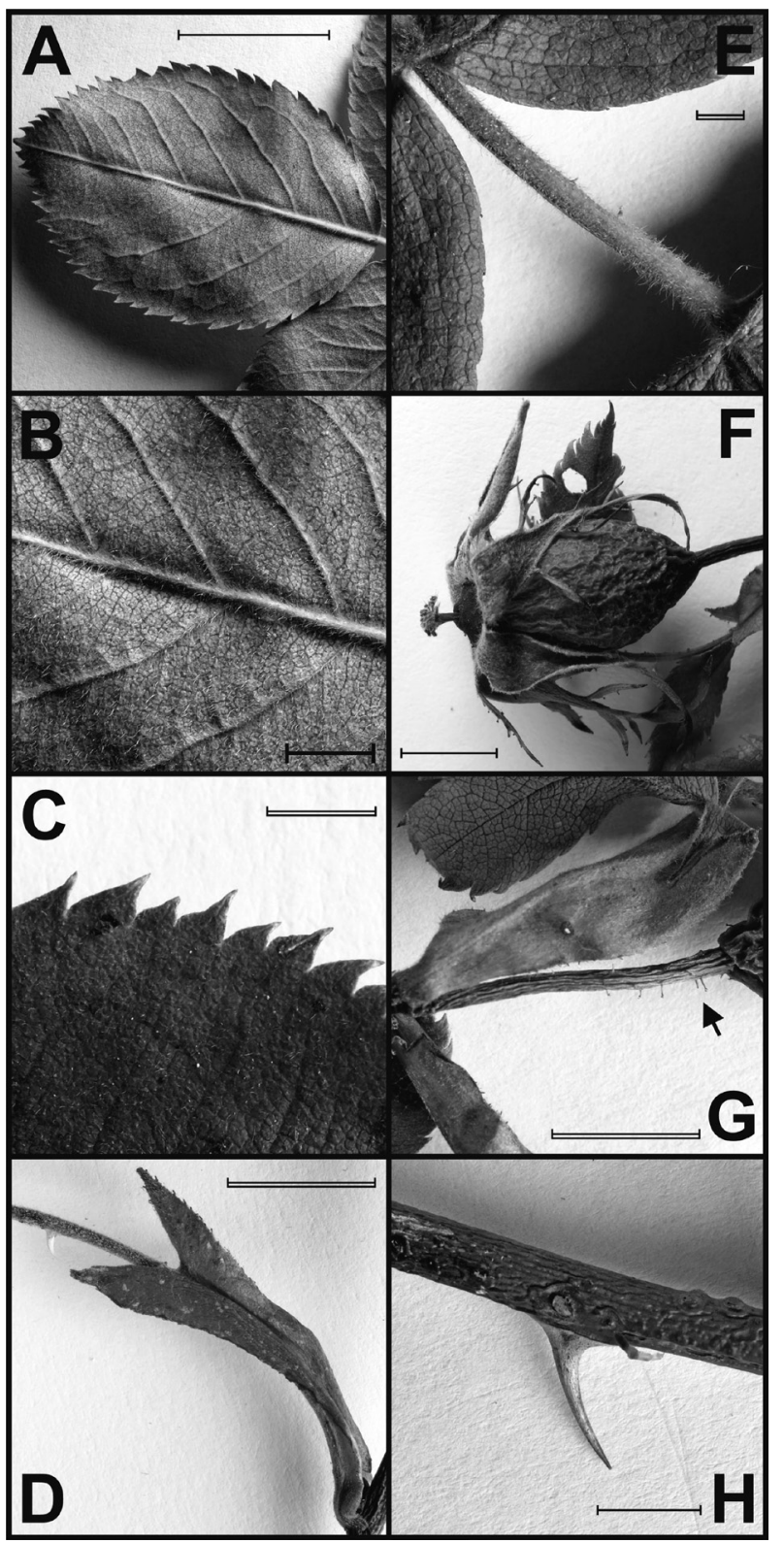

Fig. 6. Rosa canina L. var. deseglisei (Boreau) Crépin Explanations: A - leaflet, B - part of a leaf (underside), C - margin of leaflet, $\mathrm{D}$ - stipule, $\mathrm{E}$ - part of leaf axis, $\mathrm{F}$ - fruit, $\mathrm{G}$ - glandular pedicel, $\mathrm{H}$ - prickle. Solid bar $=1 \mathrm{~cm}$. Double bar $=0.5 \mathrm{~cm}$ 
Rosa $\times$ subcollina $(\mathrm{H}$. Christ) R. Keller

New for the study area, a very rare taxon, 2 localities $(28,118)$ in 2 stands.

The form of hybrid origin, hairy leaves, reported by Henker (2000) in the range of species. Its distribution in Poland requires further studies. CE-M(n).

\section{Rosa canina $\mathrm{L} . \times R$. rubiginosa $\mathrm{L}$.}

New for the study area, very rare, 2 localities (70, 83 ) in 2 stands.

An interspecific hybrid, the distribution unknown. sa-CE-M(n).

\section{Sect. Synstylae DC.}

\section{Rosa multiflora Thunb.}

New for the study area, anthropophyte, very rare, 1 locality (13), close to a gravel path. The specimen may come from the local private gardens.

Specimens grow in the whole territory of Poland as escapes from cultivated areas, gardens (decorative plant) and parks (Zieliński 1987; Pacyna 2004; Gutkowska \& Niedźwiecka 2014; Wolanin 2014). Asia.

\section{Discussion}

The studies provided additional records concerning the number of species stands in Piła, which helped to prepare a more precise description of their frequency and distribution in the examined area. The examples confirming the above comprised: Rosa sherardii or, very common in the entire country, $R$. canina and $R$. dumalis, formerly obtained from single habitats only (Abromeit 1898-1940; Zieliński 1981c, 1981d). The acquired records confirmed poor recognition of the subject in the studied area.

The frequency of rose and hawthorn occurrence in the studied area ranged from 1 to 26 stands. There were found 10 very rare taxa (max. 4 stands only): Crataegus rhipidophylla, Rosa villosa and antropophytes: R. glauca, R. multiflora (1 stand for each), $C$. $\times$ media, $C$. laevigata (reported by literature), $R$. majalis, $R$. $\times$ subcollina ( 2 stands for each), $C . \times$ macrocarpa (4 stands) and the intersection hybrid $R$. canina $\times R$. rubiginosa ( 2 stands). The most frequent species were: C. monogyna (26 stands), $R$. canina (23 stands) and $R$. dumalis (14 stands). These taxa are also the most common wild growing rose and hawthorn species in Poland.

Field studies revealed also the hybrid form of $R$. canina and $R$. dumalis. The occurrence of a specimen slightly different from typical $R$. dumalis was also reported. Some scientists (Henker 2000) consider them as hybrids $(R$. dumalis $\times R$. canina $)$ and treat them as individual, separate taxa: $R$. $\times$ subcanina - with no hairy leaves, and R. $\times$ subcollina - with hairy leaves. According to other authors (Zieliński 1985, 1987), the above-mentioned specimens are morphological extremes of $R$. dumalis forms, related to typical, com-

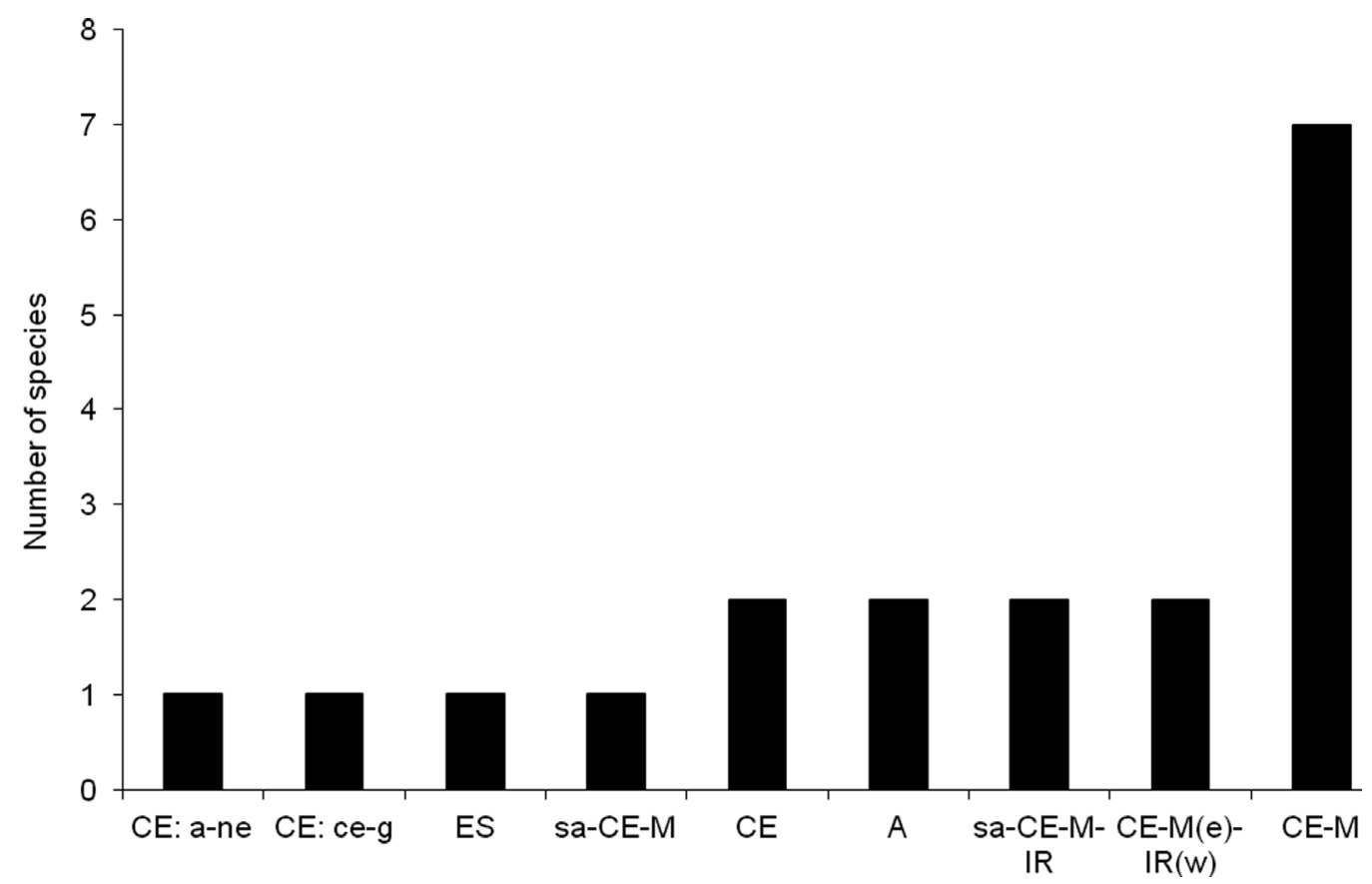

Fig. 7. Geographical elements and subelements of roses and hawthorns occurring in the study area (according to: Popek 2002, 2007; Zając \& Zajac 2009)

Explanations: A - Asian element, CE - European-temperate sub-element, CE: a-ne - Alpine-northern-European distributional type, CE: ce-g - Europeantemperate montane group, ES - Euro-Siberian sub-element, IR - Irano-Turanian element, M - Mediterranean element, e - eastern, w - western; sa - extension in the beginning of diagnosis to the Atlantic region of Europe 
mon representatives. This paper follows the approach of Henker (2000).

The highest diversity was found among $R$. canina (5 varieties) and $R$. dumalis (4 varieties). The $R$. canina varieties include, among others: $R$. canina var. canina with single serrated leaves, $R$. canina var. andegavensis with glandular pedicles and no hairy leaves and $R$. canina var. deseglise $i$ with glandular pedicles and hairy leaves. The rare varieties of $R$. canina in Poland (Popek 1996) deserve further attention (Fig. 6). So far, in Poland, $R$. canina var. andegavensis was only reported from the Wielkopolska Lowland, Sudety Foothills and Wysoczyzna Płocka, while R. canina var. deseglisei was observed in Szczecin, Silesian-Kraków Uplands, Nida Basin and Silesian Beskids (Popek 1996; Sołtys-Lelek 2011, 2012).

$R$. rubiginosa var. jenensis, with glandular pedicles, fruit and sepals is an absolute rarity in the Piła area, formerly found in the Szczecin region (Holzfuss 1924) and Solec Basin (Sołtys-Lelek 2012) in Poland. Generally, it is considered a very rare variety in the central and southern parts of Europe (Klášterský 1932). Non-glandular leaves and pedicles of rare $R$. sherardii var. collivaga were reported so far from western and northern parts of Poland (Kłodzko, Wałbrzych, Chojnów, Zielona Góra and Szczecin areas) and south of the country: The Pieniny Mountains, and KrakowskoCzęstochowska Upland (Jurassic Rock Upland) (Popek \& Szelag 1993; Popek 1996; Sołtys-Lelek 2011) belong to more interesting ones.
C. $\times$ subsphaericea nothovar. domicensis - with erect or erect to spreading sepals (Fig. 4) - belongs to the most interesting taxa among hawthorns. So far, it was reported from central and eastern Poland only (Morawica and Lublin region: Helenów and Ciecierzyn), also, from the Polish Carpathian Mts. (Christensen 1992; Oklejewicz et al. 2014).

Nothovar. macrocarpa and nothovar. calycina - two nothovarieties of $C$. ×macrocarpa - the nothospecies found in the examined area also deserve more attention; so far they were reported only from the western, southern and eastern outskirts of Poland (Christensen 1992; Oklejewicz \& Vončina 2012; Sołtys-Lelek 2011, 2012; Oklejewicz et al. 2013, 2014, 2015). There are no sufficient records concerning the distribution of this taxon in Poland, yet.

Among the above-mentioned taxa dominate the species distributed in the European territories with temperate and Mediterranean climate (Fig. 7).

The studied species belong to the floristic elements of Piła and occur in specific conditions, depending on urban infrastructure. They often grow in towns spontaneously, as a result of natural succession, or are cultivated by people as a part of urban greenery. Considering their decorative value, the following specimens were planted in the investigated area: $R$. glauca, $R$. villosa, $R$. multiflora and cultivated, remarkably beautiful $C$. $\times$ media 'Rubra Plena'. Most roses and hawthorns species originate from wasteland habitats; however, a quite

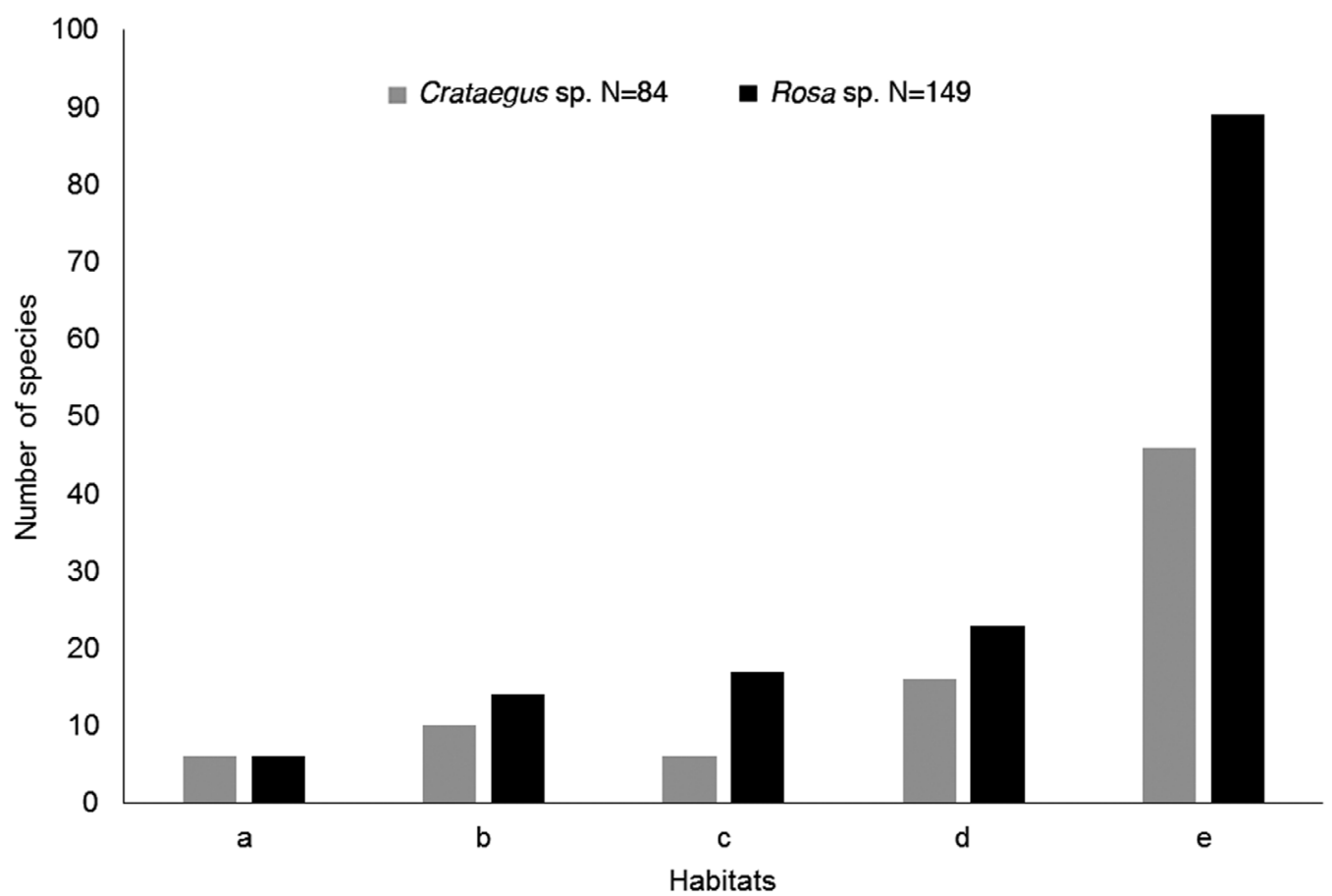

Fig. 8. Habitats of species in the study area

Explanations: $\mathrm{a}$ - forest areas, $\mathrm{b}$ - forest edges , $\mathrm{c}$ - green areas within the city borders, $\mathrm{d}$ - roadsides, $\mathrm{e}$ - wastelands 
large number of taxa was also reported from roadsides (Fig. 8). R. canina and $R$. dumalis - two most common species appearing in Poland, as well as $R$. rubiginosa were found in the above-mentioned habitats. $R$. glauca and $R$. $\times$ subcollina were the only taxa occurring in the wasteland habitats situated in the examined territory. Rosa majalis and $R$. villosa were found only in the urban green areas. C. monogyna was found in all studied stands. C. $\times$ subsphaericea was also present in all habitats besides the forests margins.

Altogether, five out of six native hawthorn species growing in Poland and over half of native rose species were observed in the examined area. The obtained results provide evidence that despite the relatively limited size of explored territory, the final effects may be spectacular. Unexpectedly, the significant number of species of the studied genera were identified within the boundaries of the town of Piła. It is very important to point out that numerous taxa found in the abovementioned area were recorded for the first time.

Acknowledgement. Special thanks to Professor Jerzy Zieliński from the Institute of Dendrology of the Polish Academy of Sciences in Kórnik near Poznań (Poland) for the help in consulting the uncharacteristic hawthorn specimens.

\section{References}

Abromeit J., Neuhoff W., Steffen H., Jentzsch A. \& Vogel G. 1898-1940. Flora von Ost- und Westpreussen herausgegeben vom Preussischen Botanischen Verein zu Königsberg (Pr.). 1148 pp. Komissionsverlag Gräfe und Unzer, Königsberg.

Barabasz-Krasny B. \& Soltys-Lelek A. 2011. Wstępne badania nad rozmieszczeniem krytycznych taksonów z rodzaju Crataegus L. i Rosa L. na odłogach Pogórza Przemyskiego. Roczniki Bieszczadzkie 19: 93-112.

Bednorz E. 2001. Pokrywa śnieżna a kierunki napływu mas powietrza w Polsce Północno-Zachodniej. 132 pp. Wyd. Naukowe UAM, Poznań.

Christensen K. I. 1992. Revision of Crataegus Sect. Crataegus and Nothosect. Crataeguineae (RosaceaeMaloideae) in the Old World. Systematic Botany Monographs. 35: 1-199.

Christensen K. I. 1997. Typification of Crataegus kyrtostyla Fingerh. In.: R. WisSKIRCHEN (ed.). Notulae ad Floram Germanicam I. Feddes Repertorium 108(1-2): 1-104.

Enderlein E. 1938. Bemerkenswerte Pflanzfunde in der Grenzmark Posen-Westpreussen, besonders in der Umgegend von Schneidemühl. Abh. Ber. Naturw. Abt. Grenzmärk. Ges. 12: 57-80.

FARAT R. (ed.) 2004. Atlas klimatu województwa wielkopolskiego. 139 pp. Instytut Meteorologii i Gospodarki Wodnej Oddział w Poznaniu, Poznań.

Frase R. 1935. Dritter Beitrag zur floristischen Durchforschung der Grenzmärk Posen-Westpreussen. Abh. Ber. Grenzm. Ges. Nat. Wiss. Abt. 10: 5-55.

Gutkowska B. \& Niedźwiecka J. 2014. Rodzaj Rosa (Rosaceae) na Pogórzu Dynowskim (SE Polska). Fragm. Flor. Geobot. Polonica 21(2): 217-227.

Henker H. 2000. Rosa. In: H. E. Weber (ed.). Gustav Hegi. Illustrierte Flora von Mitteleuropa. Band 4/2c, pp. 1-108. Parey Buchverlag, Berlin.

Holzfuss E. 1924. Die Rosen der Provinz Pommern. Abh. Ber. Pommer. Nat. Ges., Szczecin 4: 1-35.

KACZMAReK C. 1972. Rosa rubiginosa L. - róża rdzawa. In: K. Browicz (ed.). Atlas rozmieszczenia drzew i krzewów w Polsce 11: 15-17. Warszawa-Poznań.
KaCZMAREK C. 1973. Rosa elliptica Tausch - róża eliptyczna. In: K. Browicz (ed.). Atlas rozmieszczenia drzew i krzewów w Polsce 11: 9-11. WarszawaPoznań.

KLÁŠTERSKÁ I. \& KLÁŠTERSKÝ I. 1974. Cytology and some chromosome numbers of Czechoslovak roses II. Bot. Notiser 127: 328-337.

KLÁŠTERSKÝ I. 1932. Rosa jundzillii Besser var. decora Kern. et $R$. agrestis Savi var. gizellae (Borb.) Schlip. en Bohĕme. Preslia 11: 1-6.

Kondracki J. 1967. Geografia fizyczna Polski. 575 pp. Wyd. Nauk. PWN, Warszawa.

Kondracki J. 2001. Geografia regionalna Polski. 441 pp. Wyd. Nauk. PWN, Warszawa.

Koźmiński C. \& Michalska B., 2001. Atlas klimatycznego ryzyka upraw roślin w Polsce. 81 pp. AR Szczecin i Uniwersytet Szczeciński, Szczecin.

LedA M. 2001a. Crataegus laevigata (Poir.) DC. In: A. ZAJĄC \& M. ZAJĄC (eds.). Distribution Atlas of Vascular Plants in Poland, p. 178. Edited by Laboratory of Computer Chorology, Institute of Botany, Jagiellonian University, Cracow.

LedA M. 2001b. Crataegus monogyna Jacq. In: A. ZAJĄC \& M. ZAJĄC (eds.). Distribution Atlas of Vascular Plants in Poland, p. 178. Edited by Laboratory of Computer Chorology, Institute of Botany, Jagiellonian University, Cracow.

Marciniuk J., Marciniuk P., Oklejewicz K. \& Wolanin M. 2015. Running wild of Rosa rugosa in the Polish Carpathians. In: V. KerÉnyi-Nagy, O. Szirmai, L. Helyes, K. Penksza \& A. Neményi (eds.). "1st Rose- and Hawthorn conference in Carpathian Basin" International conference 29-30th may 2015, pp. 235-236. Godolló (Hungary) Proceedings-Book.

Matuszkiewicz J. M. 2008. Regionalizacja geobotaniczna Polski. 358 pp. IGiPZ, PAN, Warszawa.

Nybom H., Carlson-Nilsson U., Werlemark G. \& Uggla M. 1997. Different levels of morphometric variation in three heterogamous dogrose species (Rosa Sect. Caninae). Pl. Syst. Evol. 204: 207-224. 
Oklejewicz K., Chwastek E., Szewczyk M., Bobiec A. \& MitKA J. 2013. Distribution of Crataegus (Rosaceae) in S-E Poland along a gradient of anthropogenic influence. Pol J Ecol 61(4): 683-691.

Oklejewicz K., Chwastek E., Szewczyk M., Ortyl B. \& MitKA J. 2014. Chorologiczne aspekty występowania głogów w Karpatach Polskich. 210 pp. Wyd. Uniwersytetu Rzeszowskiego, Rzeszów.

Oklejewicz K., Szewczyk M. \& Wolanin M. 2015. Rodzaj Crataegus w Bieszczadach. Roczniki Bieszczadzkie 23: $55-70$.

Oklejewicz K. \& Vončina G. 2012. Rodzaj Crataegus w Pieninach. Przyroda i Człowiek 12: 71-79.

Pacyna A. 2004. Rośliny naczyniowe wschodniej części Pogórza Wielickiego i przylegającej części Beskidów (Karpaty Zachodnie). Prac. Bot. 38: 1-367.

Popek R. 1996. Biosystematyczne studia nad rodzajem Rosa L. w Polsce i krajach ościennych. Prace Monograficzne WSP 218, 199 pp. Kraków.

Popek R. 2002. Róże dziko rosnące Polski. Klucz-Atlas. 112 pp. Plantpress, Kraków.

Popek R. \& Szeląg Z. 1993. Róże Pienin. Fragm. Flor. Geobot. 38(1): 227-235.

Program ochrony środowiska dla gminy Piła na lata 20052012. 99 pp. Urząd Miasta Piła, Piła (http://www.pila. $\mathrm{pl} / \mathrm{pl} /$ program-ochrony-srodowiska-dla-gminy-pila. html)

PTAK K. 1986. Cyto-embryological investigations on the Polish representatives of the genus Crataegus L. I. Chromosome numbers; embryology of diploid and tetraploid species. Acta Biologica Cracoviensia ser. Botanica 28: 107-122.

PTAK K. 1989. Cyto-embryological investigations on the Polish representatives of the genus Crataegus L. II. Embryology of the triploid species. Acta Biologica Cracoviensia ser. Botanica 31: 97-112.

Seneta W. 1994. Drzewa i krzewy liściaste. 2, 318 pp. Wyd. Nauk. PWN, Warszawa.

Soltys-Lelek A. 2011. Chorologia krytycznych rodzajów - Crataegus L., Rosa L., Rubus L. na Wyżynie Krakowsko-Częstochowskiej. Prądnik. Prace Muz. Szafera 21: 5-109.

SoŁtys-Lelek A. 2012. Crataegus and Rosa genera in the Solec Basin and southern part of the Pińczów Hummock (Southern Poland). Biodiv. Res. Conserv. 25: 55-66.

Wells T. C. \& Phipps J. B. 1989. Studies in Crataegus (Rosaceae: Maloideae). XX. Interserial hybridization between Crataegus monogyna (series Oxyacanthae) and Crataegus punctata (series Punctatae) in southern Ontario. Can J Botany 67: 2465-2472.

Werlemark G. 2000. Evidence of apomixis in hemisexual dogrose species. Rosa sect. Caninae. Sexual Plant Reprod 12: 353-359.

Wolanin M. 2014. Rośliny naczyniowe Pogórza Przemyskiego i zachodniej części Płaskowyżu Chyrowskiego. Prac. Bot. 47: 1-383.
ZAJĄC A. 1978. Założenia metodyczne Atlasu rozmieszczenia roślin naczyniowych w Polsce. Wiad. Bot. 22(3): 144-145.

ZajĄC A. \& ZajĄC M. (eds.). 2001. Distribution Atlas of Vascular Plants in Poland. xii+714 pp. Edited by Laboratory of Computer Chorology, Institute of Botany, Jagiellonian University, Cracow.

ZAJAcC M. \& ZAJAcC A. 2009. The geographical elements of native flora of Poland. $94 \mathrm{pp}$. Edited by Laboratory of Computer Chorology, Institute of Botany, Jagiellonian University, Kraków.

Zieliński J. 1981a. Rosa sherardii Davies - róża Sherarda. In: K. Browicz (ed.). Atlas rozmieszczenia drzew i krzewów w Polsce 32: 19-20. Warszawa-Poznań.

ZiELIŃSKi J. 1981b. Rosa majalis J. Herrmann - róża girlandowa. In: K. BRowicz (ed.). Atlas rozmieszczenia drzew i krzewów w Polsce 32: 9-10. Warszawa-Poznań.

ZielińSKi J. 1981c. Rosa dumalis Bechst. em. Bouleng. - róża sina In: K. Browicz (ed.). Atlas rozmieszczenia drzew i krzewów w Polsce 32: 15-16. Warszawa-Poznań.

ZIELIŃSKi J. 1981d. Rosa villosa L. - róża jabłkowata. In: K. BRowicz (ed.). Atlas rozmieszczenia drzew i krzewów w Polsce 32: 21-23. Warszawa-Poznań.

ZielińsKi J. 1981e. Rosa canina L. - róża dzika. W: In: K. BRowicz (ed.). Atlas rozmieszczenia drzew i krzewów w Polsce 32: 13-14. Warszawa-Poznań.

ZIELIŃSKI J. 1985. Studia nad rodzajem Rosa L. - systematyka sekcji Caninae DC. em Christ.. Kórnickie 30: 3-109.

Zieliński J. 1987. Rosa L. In: A. JAsiewicz (ed.). Flora Polski, 5, 48 pp. Instytut Botaniki, Polska Akademia Nauk, Kraków.

Zieliński J. \& Popek R. 2001a. Rosa majalis Herrm. In: A. ZAJĄC \& M. ZAJĄC (eds.). Distribution Atlas of Vascular Plants in Poland, p. 455. Edited by Laboratory of Computer Chorology, Institute of Botany, Jagiellonian University, Cracow.

Zieliński J. \& Popek R. 2001b. Rosa dumalis Bechst. em. Boulenger. In: A. ZaJĄC \& M. ZaJĄC (eds.). Distribution Atlas of Vascular Plants in Poland, p. 454. Edited by Laboratory of Computer Chorology, Institute of Botany, Jagiellonian University, Cracow.

Zieliński J. \& POPEK R. 2001c. Rosa villosa L. In: A. ZAJĄC \& M. ZAJĄC (eds.). Distribution Atlas of Vascular Plants in Poland, p. 457. Edited by Laboratory of Computer Chorology, Institute of Botany, Jagiellonian University, Cracow.

ZielińsKi J. \& PopeK R. 2001d. Rosa sherardii Davies. In: A. ZAJĄC \& M. ZAJĄC (eds.). Distribution Atlas of Vascular Plants in Poland, p. 457. Edited by Laboratory of Computer Chorology, Institute of Botany, Jagiellonian University, Cracow.

Zieliński J. \& POPEK R. 2001e. Rosa canina L. In: A. ZAJAcC \& M. ZAJĄC (eds.). Distribution Atlas of Vascular Plants in Poland, p. 454. Edited by Laboratory of Computer Chorology, Institute of Botany, Jagiellonian University, Cracow. 
Appendix 1. Coordinates of localities of Crataegus species

Stand: BC1724

Localities

1. $53^{\circ} 11^{\prime} 13.35^{\prime \prime} \mathrm{N} ; 16^{\circ} 44^{\prime} 58.64^{\prime \prime} \mathrm{E}$

2. $53^{\circ} 11^{\prime} 4.51^{\prime \prime} \mathrm{N} ; 16^{\circ} 45^{\prime} 1.08^{\prime \prime} \mathrm{E}$

3. $53^{\circ} 11^{\prime} 17.43^{\prime \prime} \mathrm{N} ; 16^{\circ} 44^{\prime} 45.65^{\prime \prime} \mathrm{E}$

4. $53^{\circ} 11^{\prime} 17.53^{\prime \prime} \mathrm{N} ; 16^{\circ} 44^{\prime} 45.22^{\prime \prime} \mathrm{E}$

5. $53^{\circ} 11^{\prime} 17.45^{\prime \prime} \mathrm{N} ; 16^{\circ} 44^{\prime} 24.66^{\prime \prime} \mathrm{E}$

6. $53^{\circ} 11^{\prime} 21.30^{\prime \prime} \mathrm{N} ; 16^{\circ} 44^{\prime} 36.55^{\prime \prime} \mathrm{E}$

Stand: BC1732

7. $53^{\circ} 10^{\prime} 30.53^{\prime \prime} \mathrm{N} ; 16^{\circ} 41^{\prime} 23.35^{\prime \prime} \mathrm{E}$

8. $53^{\circ} 9^{\prime} 42.33^{\prime \prime N} \mathrm{~N} ; 16^{\circ} 41^{\prime} 13.47^{\prime \prime} \mathrm{E}$

Stand: BC1733

9. $53^{\circ} 10^{\prime} 42.89^{\prime \prime} \mathrm{N} ; 16^{\circ} 43^{\prime} 55.61 " \mathrm{E}$

10. $53^{\circ} 9^{\prime} 59.88^{\prime \prime} \mathrm{N} ; 16^{\circ} 43^{\prime} 20.76^{\prime \prime} \mathrm{E}$

11. $53^{\circ} 10^{\prime} 0.83^{\prime \prime N} ; 16^{\circ} 43^{\prime} 21.63^{\prime \prime} \mathrm{E}$

Stand: BC1734

12. $53^{\circ} 10^{\prime} 26.24^{\prime \prime} \mathrm{N} ; 16^{\circ} 43^{\prime} 36.73^{\prime \prime} \mathrm{E}$

13. $53^{\circ} 10^{\prime} 33.53^{\prime \prime} \mathrm{N} ; 16^{\circ} 43^{\prime} 50.86^{\prime \prime} \mathrm{E}$

14. $53^{\circ} 10^{\prime} 33.55^{\prime \prime} \mathrm{N} ; 16^{\circ} 44^{\prime} 32.45^{\prime \prime} \mathrm{E}$

15. $53^{\circ} 10^{\prime} 36.16^{\prime \prime} \mathrm{N} ; 16^{\circ} 43^{\prime} 48.89^{\prime \prime} \mathrm{E}$

16. $53^{\circ} 11^{\prime} 14.84^{\prime \prime N} ; 16^{\circ} 45^{\prime} 7.55^{\prime \prime} \mathrm{E}$

17. $53^{\circ} 10^{\prime} 45.90^{\prime \prime} \mathrm{N} ; 16^{\circ} 44^{\prime} 48.04^{\prime \prime} \mathrm{E}$

18. $53^{\circ} 10^{\prime} 19.19^{\prime \prime N} ; 16^{\circ} 45^{\prime} 10.47^{\prime \prime} \mathrm{E}$

19. $53^{\circ} 10^{\prime} 3.51^{\prime \prime} \mathrm{N} ; 16^{\circ} 45^{\prime} 1.57^{\prime \prime} \mathrm{E}$

20. $53^{\circ} 10^{\prime} 0.44^{\prime \prime} \mathrm{N} ; 16^{\circ} 44^{\prime} 57.61 " \mathrm{E}$

21. $53^{\circ} 10^{\prime} 1.33^{\prime \prime} \mathrm{N} ; 16^{\circ} 44^{\prime} 41.66^{\prime \prime} \mathrm{E}$

22. $53^{\circ} 10^{\prime} 31.18^{\prime \prime} \mathrm{N} ; 16^{\circ} 43^{\prime} 30.22^{\prime \prime} \mathrm{E}$

23. $53^{\circ} 10^{\prime} 34.16^{\prime \prime} \mathrm{N} ; 16^{\circ} 44^{\prime} 47.66^{\prime \prime} \mathrm{E}$

24. $53^{\circ} 9^{\prime} 59.80^{\prime \prime} \mathrm{N} ; 16^{\circ} 44^{\prime} 39.68^{\prime \prime} \mathrm{E}$

25. $53^{\circ} 9^{\prime} 49.56^{\prime \prime} \mathrm{N} ; 16^{\circ} 44^{\prime} 26.90^{\prime \prime} \mathrm{E}$

26. $53^{\circ} 10^{\prime} 6.34^{\prime \prime} \mathrm{N} ; 16^{\circ} 44^{\prime} 47.20^{\prime \prime} \mathrm{E}$

Stand: BC1742

27. $53^{\circ} 8^{\prime} 38.86^{\prime \prime} \mathrm{N} ; 16^{\circ} 41^{\prime} 11.39^{\prime \prime} \mathrm{E}$

28. $53^{\circ} 8^{\prime} 42.65^{\prime \prime} \mathrm{N} ; 16^{\circ} 41^{\prime} 12.32^{\prime \prime} \mathrm{E}$

29. 53 $3^{\circ} 16.06^{\prime \prime} \mathrm{N} ; 16^{\circ} 41^{\prime} 32.22 " \mathrm{E}$

30. $53^{\circ} 8^{\prime} 58.92^{\prime \prime} \mathrm{N} ; 16^{\circ} 40^{\prime} 49.53^{\prime \prime} \mathrm{E}$

31. 53 $3^{\circ} 2.77^{\prime \prime N}$; $16^{\circ} 40^{\prime} 53.19^{\prime \prime} \mathrm{E}$

32. $53^{\circ} 9^{\prime} 5.64 " \mathrm{~N} ; 16^{\circ} 41^{\prime} 18.34 " \mathrm{E}$

33. $53^{\circ} 9^{\prime} 5.64 " \mathrm{~N} ; 16^{\circ} 41^{\prime} 18.34 " \mathrm{E}$

Stand: BC1743

34. 53 $3^{\circ} 22.71 " \mathrm{~N} ; 16^{\circ} 43^{\prime} 19.37^{\prime \prime} \mathrm{E}$

35. 53 $3^{\circ} 22.89^{\prime \prime} \mathrm{N} ; 16^{\circ} 43^{\prime} 19.43^{\prime \prime} \mathrm{E}$

36. $53^{\circ} 9^{\prime} 4.13^{\prime \prime N} ; 16^{\circ} 42^{\prime} 39.82^{\prime \prime} \mathrm{E}$

37. $53^{\circ} 8^{\prime} 42.10^{\prime \prime} \mathrm{N} ; 16^{\circ} 43^{\prime} 18.12^{\prime \prime} \mathrm{E}$

38. $53^{\circ} 8^{\prime} 47.61 " \mathrm{~N} ; 16^{\circ} 43^{\prime} 17.23 " \mathrm{E}$

39. $53^{\circ} 8^{\prime} 53.32^{\prime \prime N}$; $16^{\circ} 43^{\prime} 13.05^{\prime \prime} \mathrm{E}$

40. $53^{\circ} 9^{\prime} 2.85^{\prime \prime} \mathrm{N}^{\prime} 16^{\circ} 41^{\prime} 51.23^{\prime \prime} \mathrm{E}$

Stand: BC1744

41. 53 $3^{\circ} 49.54^{\prime \prime} \mathrm{N} ; 16^{\circ} 44^{\prime} 47.70^{\prime \prime} \mathrm{E}$

42. $53^{\circ} 8^{\prime} 38.47^{\prime \prime N} ; 16^{\circ} 43^{\prime} 32.98^{\prime \prime} \mathrm{E}$

43. 53 ${ }^{\circ} 23.37^{\prime \prime} \mathrm{N} ; 16^{\circ} 44^{\prime} 30.73 " \mathrm{E}$

Stand: BC1810

44. 53ำ1'55.54"N; 16²4'22.73"E

Stand: BC1820

45. 53ำ1'28.54"N; $16^{\circ} 45^{\prime} 13.67^{\prime \prime} \mathrm{E}$

$46.53^{\circ} 11^{\prime} 11.21 " \mathrm{~N} ; 16^{\circ} 46^{\prime} 14.26^{\prime \prime} \mathrm{E}$

47. 53ำ1'22.27"N; 16 $46^{\circ} 35.30^{\prime \prime} \mathrm{E}$
Stand: BC1821

48. 531'1.07"N; 16²48'24.14"E

Stand: BC 1830

49. $53^{\circ} 10^{\prime} 15.49 " \mathrm{~N} ; 16^{\circ} 45^{\prime} 19.66^{\prime \prime} \mathrm{E}$

$50.53^{\circ} 10^{\prime} 32.26^{\prime \prime N} ; 16^{\circ} 45^{\prime} 45.47^{\prime \prime} \mathrm{E}$

$51.53^{\circ} 10^{\prime} 32.26^{\prime \prime} \mathrm{N} ; 16^{\circ} 45^{\prime} 45.47^{\prime \prime} \mathrm{E}$

52. $53^{\circ} 10^{\prime} 12.21^{\prime \prime} \mathrm{N} ; 16^{\circ} 45^{\prime} 16.14^{\prime \prime} \mathrm{E}$

Stand: BC1832

53. $53^{\circ} 10^{\prime} 31.75^{\prime \prime} \mathrm{N} ; 16^{\circ} 49^{\prime} 46.42^{\prime \prime} \mathrm{E}$

Stand: BC1840

54. 53 $3^{\circ} 52.24 " \mathrm{~N} ; 16^{\circ} 45^{\prime} 56.43^{\prime \prime} \mathrm{E}$

55. 53 $3^{\circ} 55.87^{\prime \prime} \mathrm{N} ; 16^{\circ} 46^{\prime} 31.07 " \mathrm{E}$

56. $53^{\circ} 9^{\prime} 29.49^{\prime \prime} \mathrm{N} ; 16^{\circ} 45^{\prime} 33.21^{\prime \prime} \mathrm{E}$

57. $53^{\circ} 9^{\prime} 27.20^{\prime \prime} \mathrm{N} ; 16^{\circ} 45^{\prime} 33.89^{\prime \prime} \mathrm{E}$

Stand: BC1841

58. 53 ${ }^{\circ} 8^{\prime} 52.36^{\prime \prime N}$; $16^{\circ} 47^{\prime} 9.40^{\prime \prime} \mathrm{E}$

59. 53 $3^{\circ} 50.39^{\prime \prime} \mathrm{N} ; 16^{\circ} 47^{\prime} 28.64^{\prime \prime} \mathrm{E}$

Stand: BC2702

60. 53ㅇ' ${ }^{\circ} 5.45^{\prime \prime N}$; $16^{\circ} 41^{\prime} 40.86^{\prime \prime} \mathrm{E}$

Stand: BC2703

$61.53^{\circ} 8^{\prime} 30.33^{\prime \prime} \mathrm{N} ; 16^{\circ} 42^{\prime} 38.54^{\prime \prime} \mathrm{E}$

$62.53^{\circ} 8^{\prime} 5.59^{\prime \prime} \mathrm{N} ; 16^{\circ} 43^{\prime} 18.68^{\prime \prime} \mathrm{E}$

Stand: BC2704

63. 53 $8^{\circ} 22.33^{\prime \prime N} ; 16^{\circ} 45^{\prime} 14.29^{\prime \prime} \mathrm{E}$

Stand: BC2713

64. 53 ${ }^{\circ} 7^{\prime} 15.22^{\prime \prime} \mathrm{N} ; 16^{\circ} 43^{\prime} 7.75^{\prime \prime} \mathrm{E}$

Stand: BC2724

$65.53^{\circ} 6^{\prime} 0.66^{\prime \prime} \mathrm{N} ; 16^{\circ} 44^{\prime} 18.39^{\prime \prime} \mathrm{E}$

Stand: BC2744

66. 53ํ' $4^{\prime} 16.34 " \mathrm{~N} ; 16^{\circ} 44^{\prime} 46.39^{\prime \prime} \mathrm{E}$

Stand: BC2800

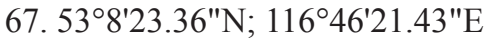

68. $53^{\circ} 8^{\prime} 22.75^{\prime \prime} \mathrm{N} ; 16^{\circ} 46^{\prime} 10.66^{\prime \prime} \mathrm{E}$

69. $53^{\circ} 8^{\prime} 23.20^{\prime \prime} \mathrm{N} ; 16^{\circ} 46^{\prime} 6.92^{\prime \prime} \mathrm{E}$

70. $53^{\circ} 8^{\prime} 21.87^{\prime \prime N} ; 16^{\circ} 45^{\prime} 59.77^{\prime \prime} \mathrm{E}$

71. 53 $3^{\circ} 13.67^{\prime \prime} \mathrm{N} ; 16^{\circ} 45^{\prime} 40.35^{\prime \prime} \mathrm{E}$

Stand: BC2801

72. 53ㅇ' $8.57^{\prime \prime N} ; 16^{\circ} 47^{\prime} 42.74^{\prime \prime} \mathrm{E}$

73. $53^{\circ} 8^{\prime} 39.68^{\prime \prime} \mathrm{N} ; 16^{\circ} 47^{\prime} 35.47^{\prime \prime} \mathrm{E}$

74. $53^{\circ} 8^{\prime} 1.40^{\prime \prime} \mathrm{N} ; 16^{\circ} 47^{\prime} 42.23^{\prime \prime} \mathrm{E}$

75. $53^{\circ} 8^{\prime} 4.93^{\prime \prime} \mathrm{N} ; 16^{\circ} 48^{\prime} 17.59^{\prime \prime} \mathrm{E}$

76. 53 ${ }^{\circ} 8^{\prime} 38.40^{\prime \prime} \mathrm{N} ; 16^{\circ} 47^{\prime} 14.58^{\prime \prime} \mathrm{E}$

Stand: BC2810

77. 53 $3^{\circ} 6^{\prime} 48.04 " \mathrm{~N} ; 16^{\circ} 46^{\prime} 31.45^{\prime \prime} \mathrm{E}$

78. 53 $3^{\circ} 26.11^{\prime \prime N} ; 16^{\circ} 46^{\prime} 21.50^{\prime \prime} \mathrm{E}$

Stand: BC2811

79. $53^{\circ} 7^{\prime} 21.26^{\prime \prime} \mathrm{N} ; 16^{\circ} 47^{\prime} 22.20^{\prime \prime} \mathrm{E}$

80. 53은 $24.27 " \mathrm{~N} ; 16^{\circ} 47^{\prime} 20.68^{\prime \prime} \mathrm{E}$

Stand: BC2820

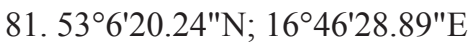

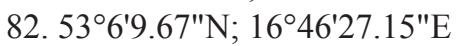

Stand: BC2830

83. 53ํ' $6^{\prime} 18.79 " \mathrm{~N}, 16^{\circ} 46^{\prime} 15.09^{\prime \prime} \mathrm{E}$

Stand: BC2821

84. $53^{\circ} 6^{\prime} 15.20^{\prime \prime} \mathrm{N} ; 16^{\circ} 46^{\prime} 42.28^{\prime \prime} \mathrm{E}$ 
Appendix 2. Coordinates of localities of Rosa species

Stand: BC1723

Locality

1. $53^{\circ} 10^{\prime} 53.11 " \mathrm{~N} ; 16^{\circ} 43^{\prime} 44.31 " \mathrm{E}$

Stand: BC1724

2. $53^{\circ} 11^{\prime} 9.37^{\prime \prime N} ; 16^{\circ} 43^{\prime} 48.48^{\prime \prime} \mathrm{E}$

3. $53^{\circ} 10^{\prime} 46.01 " \mathrm{~N} ; 16^{\circ} 44^{\prime} 47.99^{\prime \prime} \mathrm{E}$

4. $53^{\circ} 10^{\prime} 59.46^{\prime \prime} \mathrm{N} ; 16^{\circ} 44^{\prime} 4.89^{\prime \prime} \mathrm{E}$

5. $53^{\circ} 10^{\prime} 59.46^{\prime \prime} \mathrm{N} ; 16^{\circ} 44^{\prime} 4.89^{\prime \prime} \mathrm{E}$

6. $53^{\circ} 11^{\prime} 16.64^{\prime \prime} \mathrm{N} ; 16^{\circ} 45^{\prime} 1.62^{\prime \prime} \mathrm{E}$

Stand: BC1732

7. $53^{\circ} 10^{\prime} 24.19^{\prime \prime} \mathrm{N} ; 16^{\circ} 41^{\prime} 22.92^{\prime \prime} \mathrm{E}$

8. $53^{\circ} 9^{\prime} 50.85^{\prime \prime} \mathrm{N} ; 16^{\circ} 41^{\prime} 12.05^{\prime \prime} \mathrm{E}$

Stand: BC1733

9. $53^{\circ} 10^{\prime} 3.44^{\prime \prime} \mathrm{N} ; 16^{\circ} 43^{\prime} 9.18^{\prime \prime} \mathrm{E}$

10. $53^{\circ} 9^{\prime} 56.42^{\prime \prime} \mathrm{N} ; 16^{\circ} 43^{\prime} 4.14 " \mathrm{E}$

11. $53^{\circ} 9^{\prime} 48.56^{\prime \prime N} ; 16^{\circ} 43^{\prime} 2.17^{\prime \prime} \mathrm{E}$

12. $53^{\circ} 9^{\prime} 49.31 " \mathrm{~N} ; 16^{\circ} 42^{\prime} 55.69^{\prime \prime} \mathrm{E}$

13. 53 $10^{\circ} 4.13^{\prime \prime} \mathrm{N} ; 16^{\circ} 43^{\prime} 22.93^{\prime \prime} \mathrm{E}$

Stand: BC1734

14. $53^{\circ} 9^{\prime} 47.61 " \mathrm{~N} ; 16^{\circ} 43^{\prime} 39.80^{\prime \prime} \mathrm{E}$

15. $53^{\circ} 9^{\prime} 56.71 " \mathrm{~N} ; 16^{\circ} 44^{\prime} 49.35^{\prime \prime} \mathrm{E}$

16. $53^{\circ} 10^{\prime} 0.30^{\prime \prime} \mathrm{N} ; 16^{\circ} 44^{\prime} 39.98^{\prime \prime} \mathrm{E}$

17. $53^{\circ} 10^{\prime} 23.25^{\prime \prime N} ; 16^{\circ} 43^{\prime} 40.54^{\prime \prime} \mathrm{E}$

18. $53^{\circ} 10^{\prime} 31.27^{\prime \prime N} ; 16^{\circ} 43^{\prime} 30.14^{\prime \prime} \mathrm{E}$

19. $53^{\circ} 10^{\prime} 32.35^{\prime \prime} \mathrm{N} ; 16^{\circ} 43^{\prime} 47.29^{\prime \prime} \mathrm{E}$

20. $53^{\circ} 10^{\prime} 33.55^{\prime \prime N} ; 16^{\circ} 44^{\prime} 32.45^{\prime \prime} \mathrm{E}$

21. $53^{\circ} 10^{\prime} 35.24^{\prime \prime} \mathrm{N} ; 16^{\circ} 43^{\prime} 32.74^{\prime \prime} \mathrm{E}$

22. $53^{\circ} 10^{\prime} 38.16^{\prime \prime} \mathrm{N} ; 16^{\circ} 43^{\prime} 57.24 " \mathrm{E}$

23. $53^{\circ} 10^{\prime} 38.16^{\prime \prime} \mathrm{N} ; 16^{\circ} 43^{\prime} 57.24 " \mathrm{E}$

24. $53^{\circ} 10^{\prime} 46.09^{\prime \prime} \mathrm{N} ; 16^{\circ} 45^{\prime} 13.32^{\prime \prime} \mathrm{E}$

25. $53^{\circ} 10^{\prime} 1.39^{\prime \prime} \mathrm{N} ; 16^{\circ} 45^{\prime} 0.03^{\prime \prime} \mathrm{E}$

26. $53^{\circ} 10^{\prime} 16.64^{\prime \prime} \mathrm{N} ; 16^{\circ} 44^{\prime} 42.87^{\prime \prime} \mathrm{E}$

27. $53^{\circ} 10^{\prime} 19.19^{\prime \prime} \mathrm{N} ; 16^{\circ} 45^{\prime} 10.47^{\prime \prime} \mathrm{E}$

28. $53^{\circ} 10^{\prime} 36.43^{\prime \prime} \mathrm{N} ; 16^{\circ} 44^{\prime} 48.85^{\prime \prime} \mathrm{E}$

29. $53^{\circ} 10^{\prime} 36.43^{\prime \prime} \mathrm{N} ; 16^{\circ} 44^{\prime} 48.85^{\prime \prime} \mathrm{E}$

30. $53^{\circ} 10^{\prime} 43.62^{\prime \prime} \mathrm{N} ; 16^{\circ} 43^{\prime} 37.34^{\prime \prime} \mathrm{E}$ 31. $53^{\circ} 10^{\prime} 30.16^{\prime \prime N} ; 16^{\circ} 44^{\prime} 8.35^{\prime \prime} \mathrm{E}$

Stand: BC1742

32. $53^{\circ} 8^{\prime} 50.06^{\prime \prime} \mathrm{N} ; 16^{\circ} 41^{\prime} 34.12^{\prime \prime} \mathrm{E}$

33. 53 $3^{\circ} 16.41 " \mathrm{~N} ; 16^{\circ} 41^{\prime} 31.68^{\prime \prime} \mathrm{E}$

34. $53^{\circ} 8^{\prime} 36.32^{\prime \prime} \mathrm{N} ; 16^{\circ} 41^{\prime} 2.79^{\prime \prime} \mathrm{E}$

35. $53^{\circ} 8^{\prime} 39.53^{\prime \prime} \mathrm{N} ; 16^{\circ} 41^{\prime} 11.40^{\prime \prime} \mathrm{E}$

36. $53^{\circ} 9^{\prime} 0.58^{\prime \prime} \mathrm{N} ; 16^{\circ} 41^{\prime} 20.90^{\prime \prime} \mathrm{E}$

37. $53^{\circ} 9^{\prime} 18.33^{\prime \prime} \mathrm{N} ; 16^{\circ} 41^{\prime} 1.77^{\prime \prime} \mathrm{E}$

38. $53^{\circ} 9^{\prime} 21.51^{\prime \prime} \mathrm{N} ; 16^{\circ} 40^{\prime} 48.80^{\prime \prime} \mathrm{E}$

Stand: BC1743

39. $53^{\circ} 8^{\prime} 36.73^{\prime \prime N} ; 16^{\circ} 41^{\prime} 53.22^{\prime \prime} \mathrm{E}$

40. $53^{\circ} 8^{\prime} 44.86^{\prime \prime} \mathrm{N} ; 16^{\circ} 43^{\prime} 17.61 " \mathrm{E}$

$41.53^{\circ} 8^{\prime} 48.99^{\prime \prime} \mathrm{N} ; 16^{\circ} 42^{\prime} 33.57^{\prime \prime} \mathrm{E}$

42. $53^{\circ} 8^{\prime} 49.35^{\prime \prime} \mathrm{N} ; 16^{\circ} 41^{\prime} 47.34^{\prime \prime} \mathrm{E}$

43. $53^{\circ} 9^{\prime} 1.22^{\prime \prime} \mathrm{N} ; 16^{\circ} 41^{\prime} 54.10^{\prime \prime} \mathrm{E}$

44. $53^{\circ} 9^{\prime} 4.07 " \mathrm{~N} ; 16^{\circ} 42^{\prime} 54.81^{\prime \prime} \mathrm{E}$

45. $53^{\circ} 9^{\prime} 4.23^{\prime \prime} \mathrm{N} ; 16^{\circ} 42^{\prime} 42.42^{\prime \prime} \mathrm{E}$

46. 53 $3^{\circ} 4.91 " \mathrm{~N} ; 16^{\circ} 42^{\prime} 2.13^{\prime \prime} \mathrm{E}$

47. $53^{\circ} 9^{\prime} 7.12^{\prime \prime} \mathrm{N} ; 16^{\circ} 42^{\prime} 36.41^{\prime \prime} \mathrm{E}$

48. $53^{\circ} 8^{\prime} 38.95^{\prime \prime} \mathrm{N} ; 16^{\circ} 43^{\prime} 19.03^{\prime \prime} \mathrm{E}$

49. $53^{\circ} 8^{\prime} 38.95^{\prime \prime N} ; 16^{\circ} 43^{\prime} 19.03^{\prime \prime} \mathrm{E}$
50. 53 $3^{\circ} 41.74 " \mathrm{~N} ; 16^{\circ} 43^{\prime} 18.78^{\prime \prime} \mathrm{E}$

51. $53^{\circ} 8^{\prime} 42.15^{\prime \prime} \mathrm{N} ; 16^{\circ} 43^{\prime} 21.38^{\prime \prime} \mathrm{E}$ 52. $53^{\circ} 8^{\prime} 50.18^{\prime \prime} \mathrm{N}^{\prime} 16^{\circ} 42^{\prime} 2.85^{\prime \prime} \mathrm{E}$

53. 53 $3^{\circ} 10.46^{\prime \prime} \mathrm{N} ; 16^{\circ} 41^{\prime} 47.09^{\prime \prime} \mathrm{E}$ 54. 53 ${ }^{\circ} 9^{\prime} 10.46 " \mathrm{~N} ; 16^{\circ} 41^{\prime} 47.09^{\prime \prime} \mathrm{E}$ 55. 53 ${ }^{\circ} 8^{\prime} 51.44 " \mathrm{~N} ; 16^{\circ} 43^{\prime} 24.15^{\prime \prime} \mathrm{E}$ Stand: BC1744 $56.53^{\circ} 8^{\prime} 40.21^{\prime \prime} \mathrm{N}, 16^{\circ} 45^{\prime} 4.60^{\prime \prime} \mathrm{E}$ 57. $53^{\circ} 8^{\prime} 56.01 " \mathrm{~N} ; 16^{\circ} 43^{\prime} 36.12^{\prime \prime} \mathrm{E}$ 58. $53^{\circ} 9^{\prime} 18.76^{\prime \prime} \mathrm{N} ; 16^{\circ} 44^{\prime} 35.48^{\prime \prime} \mathrm{E}$ 59. 53 $3^{\circ} 42.27^{\prime \prime} \mathrm{N} ; 16^{\circ} 44^{\prime} 22.67^{\prime \prime} \mathrm{E}$ 60. 53'9'25.78"N; $16^{\circ} 44^{\prime} 32.82^{\prime \prime E}$ Stand: BC1810

61. 53ำ1'53.62"N; 16²5'25.21"E Stand: BC1820

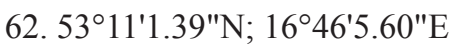
63. $53^{\circ} 11^{\prime} 7.21^{\prime \prime N} ; 16^{\circ} 46^{\prime} 7.66^{\prime \prime} \mathrm{E}$

Stand: BC1830

64. 53ำ $10^{\prime} 26.91 " \mathrm{~N} ; 16^{\circ} 45^{\prime} 47.45^{\prime \prime} \mathrm{E}$ 65. $53^{\circ} 10^{\prime} 18.21 " \mathrm{~N} ; 16^{\circ} 45^{\prime} 24.24 " \mathrm{E}$ 66. 53 $3^{\circ} 10^{\prime} 21.51 " \mathrm{~N} ; 16^{\circ} 45^{\prime} 37.13^{\prime \prime} \mathrm{E}$ 67. 53ำ $10^{\prime} 28.90^{\prime \prime} \mathrm{N} ; 16^{\circ} 45^{\prime} 30.30^{\prime \prime} \mathrm{E}$ 68. $53^{\circ} 10^{\prime} 32.16^{\prime \prime} \mathrm{N} ; 16^{\circ} 45^{\prime} 46.57^{\prime \prime} \mathrm{E}$ 69. 53 $3^{\circ} 56.61 " \mathrm{~N} ; 16^{\circ} 45^{\prime} 33.77^{\prime \prime} \mathrm{E}$ 70. 53 ${ }^{\circ} 9^{\prime} 57.36^{\prime \prime N}$; $16^{\circ} 45^{\prime} 32.10^{\prime \prime} \mathrm{E}$ 71. $53^{\circ} 9^{\prime} 57.36^{\prime \prime} \mathrm{N} ; 16^{\circ} 45^{\prime} 32.10^{\prime \prime} \mathrm{E}$ Stand: BC1831

72. 53०11'0.59"N; $16^{\circ} 48^{\prime} 24.18^{\prime \prime} \mathrm{E}$

73. $53^{\circ} 10^{\prime} 10.84^{\prime \prime} \mathrm{N} ; 16^{\circ} 48^{\prime} 27.39^{\prime \prime} \mathrm{E}$ Stand: BC1832

74. $53^{\circ} 10^{\prime} 37.19^{\prime \prime} \mathrm{N} ; 16^{\circ} 49^{\prime} 47.59^{\prime \prime} \mathrm{E}$

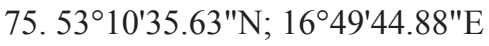
Stand: BC1840

76. 53 $3^{\circ} 26.39^{\prime \prime} \mathrm{N} ; 16^{\circ} 45^{\prime} 34.66^{\prime \prime} \mathrm{E}$ 77. $53^{\circ} 9^{\prime} 27.50^{\prime \prime} \mathrm{N} ; 16^{\circ} 45^{\prime} 34.06^{\prime \prime} \mathrm{E}$ 78. $53^{\circ} 8^{\prime} 3.68^{\prime \prime} \mathrm{N} ; 16^{\circ} 42^{\prime} 26.98^{\prime \prime} \mathrm{E}$ 79. $53^{\circ} 9^{\prime} 22.90^{\prime \prime} \mathrm{N} ; 16^{\circ} 45^{\prime} 25.56^{\prime \prime} \mathrm{E}$ 80. 53 $3^{\circ} 39.76 " \mathrm{~N} ; 16^{\circ} 46^{\prime} 32.63^{\prime \prime} \mathrm{E}$ 81. 53 $3^{\circ} 13.77^{\prime \prime N} ; 16^{\circ} 46^{\prime} 11.98^{\prime \prime} \mathrm{E}$ 82. 53 ${ }^{\circ} 9^{\prime} 38.37 " \mathrm{~N} ; 16^{\circ} 46^{\prime} 31.57^{\prime \prime} \mathrm{E}$ 83. 53 $8^{\circ} 52.20^{\prime \prime} \mathrm{N} ; 16^{\circ} 45^{\prime} 51.98^{\prime \prime} \mathrm{E}$ Stand: BC1841

84. 53 $8^{\circ} 57.58^{\prime \prime} \mathrm{N} ; 16^{\circ} 47^{\prime} 29.17^{\prime \prime} \mathrm{E}$ Stand: BC2702

85. 53 $3^{\circ} 37.03 " \mathrm{~N} ; 16^{\circ} 40^{\prime} 53.78^{\prime \prime} \mathrm{E}$ 86. $53^{\circ} 7^{\prime} 55.49^{\prime \prime} \mathrm{N} ; 16^{\circ} 41^{1} 5.04^{\prime \prime} \mathrm{E}$ 87. $53^{\circ} 7^{\prime} 55.49^{\prime \prime} \mathrm{N} ; 16^{\circ} 41^{\prime} 5.04^{\prime \prime} \mathrm{E}$ Stand: BC2703

88. 53ㅇ' $30.89^{\prime \prime N}$; $16^{\circ} 42^{\prime} 6.11^{\prime \prime} \mathrm{E}$ 89. $53^{\circ} 8^{\prime} 31.49^{\prime \prime} \mathrm{N} ; 16^{\circ} 42^{\prime} 7.55^{\prime \prime} \mathrm{E}$ 90. $53^{\circ} 8^{\prime} 12.17^{\prime \prime N} ; 16^{\circ} 43^{\prime} 2.72^{\prime \prime} \mathrm{E}$ 91. 53 ${ }^{\circ} 8^{\prime} 25.24 " \mathrm{~N} ; 16^{\circ} 42^{\prime} 47.85^{\prime \prime} \mathrm{E}$ 92. 53 ${ }^{\circ} 8^{\prime} 32.29^{\prime \prime} \mathrm{N} ; 16^{\circ} 42^{\prime} 41.63^{\prime \prime} \mathrm{E}$ 93. $53^{\circ} 8^{\prime} 33.46^{\prime \prime} \mathrm{N} ; 16^{\circ} 42^{\prime} 43.42^{\prime \prime} \mathrm{E}$ 94. $53^{\circ} 8^{\prime} 33.46 " \mathrm{~N} ; 16^{\circ} 42^{\prime} 43.42^{\prime \prime} \mathrm{E}$ 95. 53 ${ }^{\circ} 8^{\prime} 37.00^{\prime \prime} \mathrm{N} ; 16^{\circ} 43^{\prime} 22.76^{\prime \prime} \mathrm{E}$ 96. 53ำ $58.63^{\prime \prime N} ; 16^{\circ} 42^{\prime} 1.49^{\prime \prime} \mathrm{E}$ 
97. $53^{\circ} 8^{\prime} 11.45^{\prime \prime} \mathrm{N} ; 16^{\circ} 42^{\prime} 14.02^{\prime \prime} \mathrm{E}$ 98. 53ㅇ' $6.81^{\prime \prime} \mathrm{N} ; 16^{\circ} 42^{\prime} 18.30^{\prime \prime} \mathrm{E}$ 99. $53^{\circ} 8^{\prime} 3.68^{\prime \prime} \mathrm{N} ; 16^{\circ} 42^{\prime} 26.98^{\prime \prime} \mathrm{E}$ 100. $53^{\circ} 8^{\prime} 9.05^{\prime \prime} \mathrm{N} ; 16^{\circ} 42^{\prime} 15.56^{\prime \prime} \mathrm{E}$ Stand: BC2704

101. 53 ${ }^{\circ} 8^{\prime} 0.08^{\prime \prime} \mathrm{N} ; 16^{\circ} 44^{\prime} 46.59^{\prime \prime} \mathrm{E}$ 102. $53^{\circ} 7^{\prime} 52.62^{\prime \prime} \mathrm{N} ; 16^{\circ} 44^{\prime} 53.99^{\prime \prime} \mathrm{E}$ 103. $53^{\circ} 8^{\prime} 22.25^{\prime \prime} \mathrm{N} ; 16^{\circ} 45^{\prime} 10.07^{\prime \prime} \mathrm{E}$ 104. $53^{\circ} 8^{\prime} 21.95^{\prime \prime} \mathrm{N} ; 16^{\circ} 45^{\prime} 14.07^{\prime \prime} \mathrm{E}$ 105. $53^{\circ} 8^{\prime} 31.04^{\prime \prime} \mathrm{N} ; 16^{\circ} 44^{\prime} 26.04^{\prime \prime} \mathrm{E}$ 106. $53^{\circ} 8^{\prime} 31.27^{\prime \prime N}$; $16^{\circ} 44^{\prime} 29.58^{\prime \prime} \mathrm{E}$ 107. 53॰8'31.31"N; $16^{\circ} 44^{\prime} 23.57^{\prime \prime} \mathrm{E}$ 108. 53ㅇ' $32.48^{\circ} \mathrm{N} ; 16^{\circ} 44^{\prime} 32.94^{\prime \prime} \mathrm{E}$ 109. 53॰8'29.84"N; $16^{\circ} 43^{\prime} 45.64^{\prime \prime} \mathrm{E}$ Stand: BC2713

110. 53 $3^{\circ} 23.65^{\prime \prime N} ; 16^{\circ} 43^{\prime} 11.32^{\prime \prime} \mathrm{E}$ 111. 53 ${ }^{\circ} 17.19^{\prime \prime N}$; $16^{\circ} 43^{\prime} 15.03^{\prime \prime} \mathrm{E}$ Stand: BC2714

113. $53^{\circ} 8^{\prime} 31.40^{\prime \prime} \mathrm{N} ; 16^{\circ} 44^{\prime} 26.14^{\prime \prime} \mathrm{E}$ 113. 53०7'29.38"N; $16^{\circ} 43^{\prime} 53.45^{\prime \prime} \mathrm{E}$ 114. $53^{\circ} 6^{\prime} 52.27^{\prime \prime N} ; 16^{\circ} 45^{\prime} 3.26^{\prime \prime} \mathrm{E}$ Stand: BC2724

115. 53ํำ $42.97^{\prime \prime N} ; 16^{\circ} 44^{\prime} 40.82^{\prime \prime} \mathrm{E}$ 116. 53०5'55.84"N; $16^{\circ} 45^{\prime} 3.60^{\prime \prime} \mathrm{E}$ Stand: BC2800

117. 53 $3^{\circ} 39.00^{\prime \prime} \mathrm{N} ; 16^{\circ} 45^{\prime} 34.05^{\prime \prime} \mathrm{E}$ 118. 53०7'42.14"N; $16^{\circ} 45^{\prime} 37.74^{\prime \prime} \mathrm{E}$ 119. $53^{\circ} 7^{\prime} 42.14^{\prime \prime N} ; 16^{\circ} 45^{\prime} 37.74^{\prime \prime} \mathrm{E}$ 120. 53०8'13.77"N; $16^{\circ} 45^{\prime} 26.55^{\prime \prime} \mathrm{E}$ 121. 53०8'19.14"N; $16^{\circ} 46^{\prime} 25.69^{\prime \prime} \mathrm{E}$ 122. 53०8'28.57"N; $16^{\circ} 45^{\prime} 45.26^{\prime \prime} \mathrm{E}$ 123. 53०8'19.80"N; $16^{\circ} 46^{\prime} 17.00^{\prime \prime} \mathrm{E}$
124. 53०8'26.63"N; $16^{\circ} 45^{\prime} 58.40^{\prime \prime} \mathrm{E}$ 125. 53०8'31.30"N; $16^{\circ} 45^{\prime} 44.33^{\prime \prime} \mathrm{E}$ 126. 53०7'40.79"N; $16^{\circ} 46^{\prime} 58.65^{\prime \prime} \mathrm{E}$ Stand: BC2801

127. 53०8'36.37"N; 6 $47^{\circ} 40.29^{\prime \prime} \mathrm{E}$

128. 53०8'36.37"N; $16^{\circ} 47^{\prime} 37.24^{\prime \prime} \mathrm{E}$ 129. $53^{\circ} 8^{\prime} 35.02^{\prime \prime} \mathrm{N} ; 16^{\circ} 47^{\prime} 46.49^{\prime \prime} \mathrm{E}$ 130. 53 $3^{\circ} 54.42^{\prime \prime} \mathrm{N} ; 16^{\circ} 48^{\prime} 2.22^{\prime \prime} \mathrm{E}$ 131. $53^{\circ} 7^{\prime} 55.59^{\prime \prime} \mathrm{N} ; 16^{\circ} 47^{\prime} 59.31^{\prime \prime} \mathrm{E}$ 132. $53^{\circ} 8^{\prime} 40.09^{\prime \prime} \mathrm{N} ; 16^{\circ} 47^{\prime} 15.79^{\prime \prime} \mathrm{E}$ 133. 53 ${ }^{\circ} 8^{\prime} 7.34^{\prime \prime} \mathrm{N}, 16^{\circ} 48^{\prime} 12.02^{\prime \prime} \mathrm{E}$ 134. 53 ${ }^{\circ} 8^{\prime} 8.04^{\prime \prime} \mathrm{N} ; 16^{\circ} 47^{\prime} 41.14 " \mathrm{E}$ 135. 53ㅇ' $28.83^{\prime \prime N} ; 16^{\circ} 47^{\prime} 11.67^{\prime \prime} \mathrm{E}$ Stand: BC2810

136. 536'54.25"N; $16^{\circ} 46^{\prime} 31.63 " \mathrm{E}$ 137. $53^{\circ} 6^{\prime} 44.88^{\prime \prime} \mathrm{N} ; 16^{\circ} 46^{\prime} 32.99^{\prime \prime} \mathrm{E}$ 138. $53^{\circ} 6^{\prime} 44.88^{\prime \prime} \mathrm{N} ; 16^{\circ} 46^{\prime} 32.99^{\prime \prime} \mathrm{E}$ 139. $53^{\circ} 7^{\prime} 30.64^{\prime \prime N} ; 16^{\circ} 45^{\prime} 42.87^{\prime \prime} \mathrm{E}$ 140. 53०7'33.43"N; $16^{\circ} 46^{\prime} 21.53^{\prime \prime} \mathrm{E}$ Stand: BC2811

141. 536'58.30"N; $16^{\circ} 47^{\prime} 28.67^{\prime \prime} \mathrm{E}$ 142. 53०7'18.33"N; 16²4'32.93"E Stand: BC2812

143. 53०7'19.86"N; 16²4'15.23"E 144. 53०7'21.94"N; 1649'9.89"E Stand: BC2820

145. 536'14.80"N; $16^{\circ} 46^{\prime} 54.15^{\prime \prime} \mathrm{E}$ 146. $53^{\circ} 6^{\prime} 19.31^{\prime \prime N} ; 16^{\circ} 466^{\prime} 27.55^{\prime \prime} \mathrm{E}$ 147. $53^{\circ} 6^{\prime} 20.27^{\prime \prime N} ; 16^{\circ} 46^{\prime} 17.74 " \mathrm{E}$ 148. $53^{\circ} 6^{\prime} 16.90^{\prime \prime} \mathrm{N} ; 16^{\circ} 46^{\prime} 58.66^{\prime \prime} \mathrm{E}$ 149. $53^{\circ} 6^{\prime} 13.47^{\prime \prime} \mathrm{N} ; 16^{\circ} 46^{\prime} 32.20^{\prime \prime}$ 